Cuervo Críales, Beatriz Del Pilar. Ovalle Páez, Sergio Arturo, "Contextualización Histórica y Normativa del Delito Político en el Marco del Conflicto Armado Colombiano", Nuevo Foro Penal, 95, (2020).

\title{
Contextualización Histórica Y Normativa Del Delito Político En El Marco Del Conflicto Armado Colombiano*
}

\section{"Historical and Normative Contextualization of Political Crime in the Framework of the Colombian Armed Conflict"}

\author{
Beatriz Del Pilar Cuervo Críales** \\ Sergio Arturo Ovalle Páez ${ }^{* *}$
}

Fecha de recepción: 23/04/2020. Fecha de aceptación: 03/10/2020

DOI: $10.17230 / \mathrm{nfp} 16.95 .4$

\section{Resumen}

El presente escrito busca mostrar que en los procesos de desmovilización y acuerdos con los grupos armados alzados en armas, el Estado colombiano ha actuado bajo un patrón de incumplimiento de lo pactado a lo largo de la historia y para ello, se hace una descripción del contexto histórico en cada escenario, hasta llegar al Acuerdo suscrito entre el Gobierno Nacional y las FARC-EP en el que se estableció el marco para la creación del SIVJRNR.

* El artículo corresponde a uno de los productos elaborados en el marco del proyecto de investigación "La muerte del delito político en la Justicia Transicional" desarrollado entre el año 2018 y el 2019 por parte del Semillero de Investigación Atenea de la Universidad Autónoma de Colombia. Bogotá, Colombia.

* Dra. en Derecho y Ciencia Política por la Universidad de Barcelona UB, Magister en Derecho y Especialista en Instituciones Jurídico Penales de la Universidad Nacional de Colombia, Abogada, Docente e Investigadora de la Universidad Autónoma de Colombia y Defensora Publica. bettycriales@ yahoo.es

** Estudiante de la Facultad de Derecho de la Universidad Autónoma de Colombia e integrante del Semillero de Investigación Atenea. ovalle.sergio@fuac.edu.co 
El interrogante que surge es ipor qué el Estado mantiene en el Acuerdo de La Habana el patrón de incumplimiento de los procesos de desmovilización que le antecedieron? para concluir, que una vez que los desmovilizados de los grupos deponen las armas, el Estado ya no tiene que combatirlos, sus obligaciones dejan de ser vinculantes y como consecuencia de ello, el Estado cumple su propósito de continuar la guerra "... abatir al adversario e incapacitarlo para que no pueda proseguir con su resistencia". ". . . imponer nuestra voluntad al enemigo es el objetivo. ${ }^{1}$

\section{Abstract}

This document seeks to show that in the demobilization processes and agreements with armed groups raised in arms, the Colombian State has acted under a pattern of noncompliance with what has been agreed throughout history and for this, a description of the historical context is made in each scenario, until reaching the Agreement signed between the National Government and the FARC-EP in which the framework for the creation of the SIVJRNR was established.

The question that arises is why does the State also maintain in the Havana Agreement the pattern of non-compliance with the demobilization processes that preceded it? To conclude, that once the demobilized groups lay down their arms, the State no longer has to fight them, their obligations cease to be binding and as a consequence of this, the State fulfills its purpose of continuing the war "... to bring down the adversary and incapacitate him so that he cannot continue with his resistance ". "... Imposing our will on the enemy is the goal.

\section{Palabras clave}

Delito Político - Justicia Transicional - Conflicto armado - Criminalización - Acuerdo de Paz - Amnistía

\section{Keywords}

Political Crime - Transitional Justice - Armed Conflict - Criminalization - Peace Agreement - Amnesty

\section{Sumario}

1. Introducción. 2. Guerras civiles, amnistías y nacimiento normativo del delito político. 3. El conflicto armado desde la regeneración conservadora. 4. La rebelión de los grupos insurgentes. 5. Aproximaciones a un proceso de paz. 6. Conclusiones

1 Karl Von Clausewitz. De la guerra. (2002), 7. https://lahaine.org/amauta/b2-img/Clausewitz\%20 Karl\%20von\%20-\%20De\%20la\%20guerra.pdf 


\section{Introducción}

El presente escrito hace parte de la investigación que realizó el semillero de Investigación Atenea de la Universidad Autónoma de Colombia, en el marco del proyecto "La muerte del delito político en la justicia transicional". El objetivo es dar cuenta de cómo el Estado ha mantenido un patrón de incumplimiento de lo acordado frente a los grupos alzados en armas, del tratamiento que se le ha dado al delito político ${ }^{2}$ en diferentes momentos de la historia y de la importancia que ha tenido la figura de la amnistía en dichos escenarios.

Para lo anterior, se utilizan los métodos cualitativo y cuantitativo, acudiendo a fuentes jurisprudenciales, sentencias y audiencias de procesos de Justicia y Paz, de igual forma se acude a historiadores, sociólogos, politólogos, en tanto que la narrativa del conflicto armado debe ser interdisciplinar.

El Gobierno Nacional y las FARC-EP, suscribieron el Acuerdo Final para la terminación del conflicto armado y el logro de una paz estable y duradera -AFTC- el 26 de septiembre de 2016. Con el fin de refrendar y legitimar el acuerdo, el Presidente de la República convocó al pueblo colombiano a un plebiscito, en el cual se consideró que el Acuerdo no debía ser aprobado33; razón por la cual se efectuó un proceso de renegociación que conllevó a una nueva firma del acuerdo el 24 de noviembre de 2016 en el Teatro Colón; lo que significó que las condiciones inicialmente pactadas cambiaran y se restringiera, aún más, las posibilidades para lograr la paz.

Como resultado de diferentes momentos, etapas, y decisiones, el acuerdo se suscribió sobre seis puntos: el primero de ellos, denominado "Reforma Rural Integral", el segundo: "Participación política, Apertura Democrática para la Paz", el tercero: "Cese al Fuego y de Hostilidades bilateral y definitivo y la Dejación de las Armas", el cuarto; Solución al problema de cultivos de uso ilícito; el quinto; el Sistema Integral de Verdad, Justicia y Reparación y No repetición (SIVJRNR), el cual será escenario

2 Con el fin de abordar el delito político en la historia de Colombia, es importante tener en cuenta que, como plantea Ferrajoli, existen dos tradiciones frente al delito político - la del derecho de resistencia como justificación del delito político, cualquiera que sea, y la razón de estado como justificación de la represión, cualquiera que sea - se oponen entre sí y, sin embargo, convergen y conviven en la práctica de la política moderna: una, fundada sobre la justificación de cualquier medio por muy inmoral que sea y penalmente ilegal respecto al fin ético de la resistencia contra las perversiones tiránicas del estado, y la otra, fundada sobre la justificación de cualquier medio, incluso del más inmoral e ilegal, con el fin igualmente ético de defender al estado de los atentados internos - y no solo externos - contra su seguridad. Luigi FerRasoli. Derecho y razón. Teoría del garantismo penal. (Madrid: Editorial Trotta, 1995), 810-811

3 Plebiscito realizado el 02 de octubre de 2016, el cual dejó como resultado el 49.78\% por el SI y el $50.21 \%$ por el NO. El total de votantes fue del $37.43 \%$ del censo electoral. 
de especial atención en esta investigación; y el sexto que corresponde al tema de "Refrendación e implementación de la totalidad de lo convenido".

El anterior escenario es el que está vigente hoy en Colombia, y sobre el cual se realizará un recorrido histórico y normativo que nos permitirá entender el contexto del delito político en Colombia, la criminalización de la guerra y la negación del conflicto armado durante décadas, hasta llegar a su aparente reconocimiento mediante la creación del Sistema Integral de Verdad, Justicia, Reparación y No Repetición, “con miras a la construcción de una paz estable y duradera", y con ocasión de la firma del AFTC; pero que continua con un patrón de incumplimiento de lo acordado, excepto, en el componente de "justicia".

La justicia transicional como la conocemos hoy, esto es, como forma de buscar acuerdos tendientes al "logro de la paz" surgió en Colombia con la Ley 975 de 2005 o Ley de Justicia y Paz cuyo objeto es la desmovilización individual o colectiva de los grupos armados organizados al margen de la ley, que de manera directa o indirecta cometieron delitos durante y con ocasión del conflicto armado con el fin de lograr la verdad, la justicia, la reparación y la no repetición.

En la historia de Colombia, se pueden evidenciar algunos de los principios que son propios de la justicia transicional, como la verdad y la justicia, que se distorsionaron, y terminaron en procesos de pacificación; pero que sin embargo, son asumidos integralmente en el punto quinto del Acuerdo suscrito entre el Gobierno nacional y las FARC -EP, en lo que se denominó: SIVJRNR, como uno de los temas fundamentales para el logro de una paz estable y duradera. Como veremos, el Acuerdo suscrito el 24 de noviembre de 2016, no es la excepción; por lo que haremos una breve reseña de los antecedentes históricos del conflicto, los diferentes procesos para resolverlos y sus efectos.

El presente escrito pretende por lo tanto, realizar una reflexión sobre el contexto del conflicto armado en Colombia, mediante la descripción de las diferentes violencias a los largo de más de dos siglos y hace un recuento histórico de los diferentes sucesos en los que surgió la normatividad del delito político, de las amnistías, del nacimiento y desarrollo de la guerrilla y de los grupos de autodefensas; aspectos estos necesarios para entender el Acuerdo de la Habana, con el fin de dar respuesta al siguiente interrogante: ¿Por qué el Estado mantiene en el Acuerdo suscrito entre el Gobierno Nacional y las FARC-EP el patrón de incumplimiento de los procesos de desmovilización que le antecedieron?, y para ello, planteamos la hipótesis de trabajo en el sentido que el Estado a lo largo de la historia no ha tenido la voluntad real de acabar con el conflicto armado, sino que los procesos de desmovilización y 
amnistías han sido una forma más de continuar con la guerra, por otros medios, que han buscado debilitar a su enemigo.

\section{Guerras civiles, amnistías y nacimiento normativo del delito político}

Para abordar este tema es necesario hacer una breve narración de las guerras civiles, los acuerdos y armisticios, las consecuencias que generaron y, el origen y transformación del delito político; para evidenciar que, finalmente, son procesos cíclicos que se repiten constantemente a lo largo de nuestra historia, porque lo único que cambia son las formas, y por consiguiente, podemos hacer a partir de ello una historia externa, exterior, de la verdad. ${ }^{4}$

Desde que inició el proceso de conquista y colonización de América se presentaron sublevaciones y rebeliones, ejemplo de ello, es la rebelión de esclavos en Popayán en 1556, o en 1598 en las minas de Zaragoza, época a partir de la cual se empiezan a establecer asentamientos libres, dando origen a los denominados Palenques, lugares a los cuales llegaban esclavos que lograban liberarse del yugo de los amos y de la corona española 5 .

El antecedente más remoto de la figura de Acuerdo de Paz en nuestro país ocurre en la zona de los Montes de María en los siglos XVI y XVII. En uno de los palenques, Benkos Biohó, un cimarrón ${ }^{6}$ proveniente de Guinea Bissau, realizó hostilidades contra las autoridades por más de media década, obligando al gobernador de Cartagena a proponerle un tratado de paz en 1605, firmado siete años más tarde por las partes y, permitiendo el retorno a la vida en comunidad de la agrupación disidente. Sin embargo, una vez desarmados Benkos fue traicionado y privado de la libertad en 1619, donde permaneció hasta el 16 de marzo de 1621 cuando fue ahorcado en la plaza pública de Cartagena, por orden del gobernador García Girón. ${ }^{7}$

4 Michael Foucault. La verdad y las formas jurídicas. (Barcelona: Grijalbo, 1995), 17.

5 Jorge Palacios Preciado. "La esclavitud y la sociedad esclavista", En Manual de Historia de Colombia Tomo 1, coordinado por Jaime Jaramillo Uribe. (Procultura, Instituto Colombiano de Cultura, 1971), 339-343

6 Cimarrón hace referencia a los esclavos fugados hacia la libertad.

7 Felipe Tenorio Obando. "Amnistías en Colombia: Herramienta de engaño, herramienta política y mecanismo de reconciliación” En Justicia Transicional en Colombia: Un camino hacia la paz, coordinado por Juan Carlos Forero. (Tirant Lo Blanch, 2017), 15-61. 
Este tratado que fue incumplido por la corona española marca uno de los antecedentes más importantes en Colombia para el tema que se aborda en el texto, pues desde esta época, ha sido una constante en los acuerdos para acabar con cualquier forma de insurrección, que una vez realizada la tregua, lo que sigue es el incumplimiento y la toma de represalias.

El esclavismo en la época de la colonia constituyó una de las formas de violencia que generó la insurrección constante de los esclavos, y que a diferencia de Estados Unidos, en nuestro país, tuvo un aire de humanización desde el siglo XVIII, lo que ayudo a que otros grupos poblacionales iniciaran sus luchas contra las injusticias que se dieron en las colonias por parte de la corona española.

La relación esclavista como fuente originaria de nuevas preocupaciones de tipo social, presento una tendencia a la humanización, a la par con las crecientes rebeliones en el Virreinato entre 1750 y 1790 que generaron movimientos liderados por los esclavos en varias poblaciones en Antioquia en 1781 y en Cartago en 1785, en los que hubo alzamientos organizados que no descartaban el uso de la violencia contra los blancos. ${ }^{8}$

Como consecuencia de todos estos movimientos de insurrección por parte de los esclavos, y por las frecuentes injusticias cometidas por la corona española contra la población en las Américas, surge la denominada Revolución de los Comuneros en 1781, la cual, se generó como consecuencia de la lucha por las reivindicaciones indígenas para recuperar los resguardos, así como contra los gravámenes impuestos por la corona.

Las poblaciones de Socorro, Mogotes, Vélez, y otras localidades del nordeste, organizan un ejército de labradores, artesanos y pequeños comerciantes mestizos, indígenas y criollos bajo la conducción de José Antonio Galán, y la consigna de "Viva el rey, abajo el mal gobierno". Como resultado, se firman las "Capitulaciones"9 del 8 de junio de 1782. Al regreso de los comuneros, los líderes son aprehendidos, ejecutados y descuartizados los cuerpos para exhibir separadamente sus extremidades en las plazas de los pueblos donde había tenido origen la rebelión. ${ }^{10}$

La rebelión de los Comuneros fue una de las dos más notables sublevaciones

8 Mario Aguilera y Renán Vega Cantor. Ideal democrático y revuelta popular. (CEREC, 1998), 61.

9 El Diccionario de la Real Academia Española define las Capitulaciones como un convenio en que se estipula la rendición de un ejército, plaza o punto fortificado.

10 Yesid Reyes Alvarado. "Colombia, Entre la guerra y la paz", Revista IUSTA, (2005): 67-80. 
hispanoamericanas (la otra fue la sangrienta revuelta de Túpac Amaru en el Perú, que ocurrió exactamente al mismo tiempo), por ello, Bushnell plantea que existió una clara relación entre el proceso independentista de las colonias inglesas, con el levantamiento de los Comuneros, en tanto que, España para costear su participación en la guerra independentista de EEUU, aumentó los precios del tabaco y del aguardiente. ${ }^{11}$

Los levantamientos de finales del siglo XVIII vinieron a dar forma real a la lenta pero creciente percepción de la existencia de desequilibrios internos en la sociedad colonial. Se puso de manifiesto que la estructura social se socavaba con las aspiraciones reivindicativas de mestizos, indios y negros, surgiendo en la élite el miedo a perder su hegemonía o la conciencia de sentirse amenazados por las castas "oscuras" de la sociedad. ${ }^{12}$

Luego de este antecedente, sumado a la Revolución Francesa, la independencia de los Estados Unidos, y la situación política de Europa, se gestan los procesos de independencia latinoamericanos. Las ideas de la llustración son recogidas como impulso, instrumento y justificación de la revolución hispanoamericana, es decir, con un sentido de liberación colonial. ${ }^{13}$

Lanuevaépocainauguradaporla Independenciasecaracterizafundamentalmente porque las clases dominantes que emergen de la colonia enfrentan la tarea de dirigir políticamente la nación recién inventada. Para ello, tales clases debían desbordar el localismo colonial y superar la dispersión regional de poder, con el fin de construir una nación cultural y políticamente homogénea a partir de un Estado erigido sobre la base de una unidad administrativa del imperio español, y de una sociedad de castas y de jerarquías de poblaciones y privilegios. ${ }^{14}$

Con la lucha entre centralistas y federalistas, que originaría una guerra civil, y luego del triunfo de los federalistas, el 9 de enero de 1813, Antonio Nariño otorgó una generosa amnistía y libertad a todos los vencidos que estaban en prisión, entre los cuales se encontraba Francisco de Paula Santander.15

Sin embargo, el proceso independentista fue interrumpido por la Reconquista

11 David Bushnell. Colombia: una nación a pesar de sí misma. (Bogotá: Editorial Planeta), 52

12 Agullera y Vega Cantor, Ideal democrático y revuelta popular, 61

13 Ibíd., 74-75.

14 Fernán González. Poder y violencia en Colombia. (Bogotá: Odecofi CINEP, 2014), 180

15 Hernando Peraza Correa. Amnistías, indultos y perdones, entre la insurrección comunera y las conversaciones de la Habana. (Bogotá: Universidad Sergio Arboleda, 2014), 8. 
Española en 1815-1816; los desacuerdos entre los patriotas, la falta de experiencia de los jefes revolucionarios criollos, contribuyeron al colapso. Las fuerzas "pacificadoras" españolas encabezadas por Pablo Morillo, luego de un asalto a Cartagena por más de cien días, restablecieron la Inquisición, crearon una corte militar para juzgar a los patriotas, bajo la política del terror, diseñada para liquidar a las principales figuras militares y políticas de la Patria Boba, y al mismo tiempo, escarmentar a la población con los peligros de la desobediencia. ${ }^{16}$

Bolívar, luego de varias batallas con el ejército realista, obtuvo una victoria el 7 de agosto de 1819 en el camino entre Tunja y Boyacá, destruyó el principal contingente español al interior de la Nueva Granada logrando así, abrir el camino para que entraran a Bogotá las fuerzas patriotas proclamando la independencia. ${ }^{17}$

Durante la década del 20, en el marco de la consolidación del naciente estado, se recurre en reiteradas ocasiones a la figura de la amnistía, así, en 1827 Bolívar le concede amnistía al militar rebelde José Antonio Páez, a quien confirma como jefe civil y militar de Venezuela; en 1828 a los implicados en la conspiración septembrina contra Bolívar; en 1829 a José María Obando y sus colaboradores que se alzaron en armas en el sur del país; y la decretada por Pedro Alcántara Herrán a favor de los rebeldes de Pasto en la denominada guerra por los conventillos de 1839, dos años posterior a la reforma del régimen penal colonial. ${ }^{18}$

En 1828 se realiza la Convención de Ocaña, la cual resulta ser fracasada, el indultado Santander impartió a sus amigos consignas para participar en un levantamiento contra Bolívar. El llamado fue acogido, entre otros por José Hilario López y José María Obando, a quien posteriormente se le otorgaría amnistía bajo la condición de jurar lealtad. ${ }^{19}$

En 1832, en el marco de la creación de la Nueva Granada y con la proclamación de una nueva Constitución, fue aprobada una amnistía general para todos aquellos que tuvieran delitos políticos pendientes, esta ley fue pensada como una estrategia política para proyectar el imaginario de un nuevo comienzo que dejara atrás las

16 BushnelL, Colombia: una nación a pesar de sí misma, 75-78

17 Ibíd., 79.

18 Tenorio Obando, "Amnistías en Colombia: Herramienta de engaño, herramienta política y mecanismo de reconciliación", 24.

19 Peraza Correa, Amnistías, indultos y perdones, entre la insurrección comunera y las conversaciones de la Habana, 13. 
heridas y los odios ocasionados anteriormente. ${ }^{20}$

En 1833 se descubrió una conspiración en contra de Santander, quien fungía como presidente desde 1832. Santander ordenó reducir a los implicados. Uno de los líderes fue José Sardá, oficial de origen español. Arrestado, sufrió las represalias de Santander, quien, en uso de poderes extraordinarios, adelantó la legislación penal en lo concerniente a los delitos de conspiración, rebelión y sedición, fueron condenados 46 hombres a muerte. ${ }^{21}$

La ley extraordinaria de traición, sedición o rebelión del 3 de junio de 1833, detallaba el proceso que se debía seguir por esos delitos. Se obligaba a los jueces a practicar un sumario a los sospechosos de conspirar contra la seguridad pública; se reglamentaba el indulto en caso de que fallara la pena de muerte. Esta ley fue reformada y ajustada en 1841, en razón a las disposiciones del Código Penal de 1837. ${ }^{22}$

En razón a la situación que vivía la Nueva Granada, y el trastorno generado por la independencia, se presentó una alteración en la criminalidad y un debilitamiento del régimen político, que tendría como efecto la promulgación en 1837 del primer Código Penal Nacional, el cual sería redactado por el Consejo de Estado y el Congreso. ${ }^{23}$

Con la ley 27 de 1837 se tipificó por primera vez el delito político:

Artículo 232. Es rebelión el levantamiento o insurrección de una porción más o menos numerosa de súbditos de la república, que se alzan contra el gobierno supremo constitucional de la Nación, negándole la obediencia debida, o procurando sustraerse de ella, o haciéndole la guerra con las armas.

Artículo 233.[...] los autores principales son traidores, serán declarados infames y sufrirán la pena de muerte. ${ }^{24}$

Con la expedición del Código Penal se pretendía endurecer las penas, con el fin de desestimular futuros alzamientos armados, en concordancia con esto, se expidió

20 María Teresa Uribe. "Las guerras civiles y la negociación política: Colombia, primera mitad del siglo XIX", Revista de Estudios Sociales, (2003): 29-41.

21 Gilberto Parada García. "Una historia del delito político. Sedición, traición y rebelión en la justicia penal neogranadina (1832-1842)", Anuario Colombiano de Historia Social y de la Cultura, 39, nº 2, 110.

22 Ibíd., 111.

23 Gilberto Parada García. "Orden y revolución en la ley penal colombiana (1819-1837). Un debate historiográfico", Anuario Colombiano de Historia Social y de la Cultura, 36, n², 187.

24 Beatriz Cuervo Criales. Macrocriminalidad y política de priorización en el marco de la Justicia Transicional. (Barcelona: 2016), 245. http://diposit.ub.edu/dspace/bitstream/2445/108272/1/ BdPCC _ TESIS.pdf 
un decreto de olvido para todos los delitos políticos cometidos antes de la fecha de entrada en vigencia del Código. ${ }^{25}$

En 1839, el gobierno cerró cuatro conventos menores en Pasto, medida que impulsó una rebelión de pastusos ultrarreligiosos. La rebelión religiosa se inició en Pasto, fue reprimida aunque no del todo, a finales del mismo año. No obstante, en 1840 estalló una revuelta, no lejos de allí, al sur de Popayán, liderada por al activo general José María Obando. ${ }^{26}$

Esta guerra, daba cuenta de dos aspectos a tener en cuenta, en primer lugar, que el país estaba lejos de ser una nación políticamente unificada y, por el contrario se trataba de una suma de agrupaciones regionales y provinciales ${ }^{27}$; y en segundo lugar, que los procesos de sublevación hacen parte de la inconformidad, también en aquellos que quieren mantener el statu quo, como sucedió en la Guerra Civil de los Supremos.

El 29 de enero de 1842 se presenta un nuevo proceso de amnistía, en el cual Pedro Alcántara Herrán suscribe una exponsión ${ }^{28}$ con el general José María Obando, alzado en armas, en la que se acordó que el general se entregaría a las autoridades para someterse a juicio, así como la desmovilización de las guerrillas que lo acompañaban, pero sin la entrega de armas, y como contrapartida se otorgaba una amnistía general y sin restricciones; sin embargo, este acuerdo no fue aceptado por el presidente Márquez. ${ }^{29}$

25 URIBE, "Las guerras civiles y la negociación política: Colombia, primera mitad del siglo XIX", 38.

26 La Guerra civil de los Supremos que va de 1839 a 1841. Este conflicto se originó en San Juan de Pasto el 30 de junio de 1839, cuando varios sacerdotes se oponían a la orden del Congreso de disolver los conventos con menos de 8 frailes para usarlos en la instrucción pública se sublevaron. El alzamiento, aunque fue sofocado temporalmente dos meses después en la batalla de Buesaco, se recrudeció cuando varios caudillos regionales que pretendían reivindicaciones políticas y económicas se alzaron contra el gobierno central.

La guerra pronto se expandió por otras provincias e incluyó un conflicto fronterizo con la República del Ecuador porque allí dependía el clero de Pasto, en el momento de las tropas ecuatorianas comandadas por Juan José Flores cruzaron la frontera, estos comandantes se sublevaron en sus respectivas regiones, pero como este movimiento no contó con una dirección única fue derrotado en 1841". Extracto tomado de Audiencia Ley de Justicia y Paz. Información reservada.

27 Gonzalez, Poder y violencia en Colombia, 188-189

28 Las exponsiones eran acuerdos 0 armisticios suscritos por los comandantes militares en el teatro de las operaciones, en las cuales se negociaba un cese parcial de hostilidades que afectaba a un territorio particular, pero que no tenía efectos necesariamente sobre el conjunto de la nación. Las exponsiones procedían en empates militares o cuando una de las partes veía la posibilidad de lograr beneficios razonables sin necesidad de derramamiento de sangre. Eran ad-referéndum del gobierno nacional. Fueron una figura frecuentemente utilizada durante las guerras civiles del siglo XIX. Un ejemplo de Exponsión exitosa fue la del "Alto de las Coles" en la provincia de Antioquia en 1851. Uribe, "Las guerras civiles y la negociación política: Colombia, primera mitad del siglo XIX", 33.

lbíd., 34. 
Con la guerra de los Supremos y, hasta la consolidación del asentamiento institucional en 1863 se produjeron alrededor de 13 amnistías, cuyo factor común estuvo en la búsqueda de la reconciliación general. No obstante, es preciso señalar que los indultos y amnistías, significaban generalmente la aprobación pública por parte de los vencidos de la soberanía del vencedor, el sometimiento explícito a su orden político y la aquiescencia sobre su derecho a gobernar, recibiendo como contrapartida beneficios judiciales. ${ }^{30}$

Para los delitos políticos de rebelión, sedición, traición y conspiración, la ley del 26 de mayo de 1849, dictada bajo la administración de José Hilario López, suprimió las penas de muerte, trabajos forzados, presidio, reclusión, prisión, infamia y vergüenza pública, y las reemplazó por la expulsión del territorio nacional, pero seguían aplicando para los delitos comunes de parricidio, envenenamiento, piratería y cuadrilla de malhechores. ${ }^{31}$

En 1851, los liberales lograron amplias mayorías en ambas cámaras del Congreso, lo que les permitiría adoptar medidas radicales. Una de esas medidas, fue la decisión de abolir la esclavitud; también, se tomaron decisiones que afectaban a la iglesia católica, lo que desencadenaría una rebelión por parte de los conservadores en ese mismo año. ${ }^{32}$

Se puede afirmar que la motivación principal de la rebelión conservadora de 1851 fue el deseo de romper el dominio político del partido liberal y restaurar el control conservador sobre el gobierno nacional. Esta motivación, se vio complementada por

30 Ibíd., 36.

31 José Márouez Estrada. "La nación en el Cadalso. Pena de muerte y politización del patíbulo en Colombia 1800-1910", Revista Historia y Memoria, n5, (2012): 2.

32 La guerra civil de 1851. Esta confrontación la comenzaron terratenientes conservadores caucanos opuestos a las reformas liberales de José Hilario López, quien proclama la libertad de los esclavos el 21 de mayo de 1851, que no se había logrado a pesar de la ley de libertad de vientres promulgada en 1821; expulsó a los jesuitas, suprimió la pena de muerte y la prisión por deudas, y además consagró la libertad de prensa, y el juicio por jurados.

El 22 de mayo 1851 Los Rebeldes se pronunciaron en el sur del país, vino luego el intento la toma de San Juan de Pasto por Julio Arboleda y su posterior derrota, otros levantamientos se sucedieron en Sogamoso, Mariquita, Guatavita y el Guamo. El gobierno nombró entonces al General José María Obando como general en jefe del ejército del Sur; y al general Tomás Herrera comandante del Valle del Cauca, quienes gradualmente fueron aplacando estos enfrentamientos armados

El 1 de agosto de 1851 un piquete de guardias nacionales enfrentó la escasa fuerza de Pastor Ospina (hermano de Mariano Ospina), 20 días después Mariano Ospina Rodríguez considerado el alma de la revolución en toda la República, fue detenido. Los revoltosos se entregaron al gobierno central, y el 10 de septiembre en Rionegro, el general Herrera venció al general Borrero, otorgó indulto a todos los combatientes y se consideró extinguida la rebelión. Extracto tomado de Audiencia Ley de Justicia y Paz. Información reservada. 
otras inconformidades regionales. Principalmente las proclamas se centraban en la defensa de la iglesia y la seguridad de la propiedad. ${ }^{33}$

En mayo de 1860, Mosquera se sublevó y asumió el liderazgo de facciones liberales con la intención de derrocar al gobierno de Ospina, se intentó mediar el conflicto por medio de la exponsión de Manizales en agosto de 1860. Este acuerdo buscaba, a través de una completa amnistía a todos los implicados en el levantamiento, dar respaldo y conseguir una efectiva suspensión de las hostilidades. Sin embargo, el presidente Ospina no aprobó el acuerdo. ${ }^{34}$

No obstante, los liberales lograron superar a Ospina en julio de 1861, Mosquera se tomó Bogotá. El expresidente Ospina fue uno de los capturados durante esta toma, Mosquera había ordenado fusilarlo, sin embargo, le conmutó la pena de muerte por prisión en Cartagena, de igual forma, al cofundador del partido Conservador, José Eusebio Caro, a quién le conmutó la pena por diez años de destierro. Así, en este conflicto, se produce por primera y única vez en la historia de Colombia, un caso de rebelión triunfante. ${ }^{35}$.

Durante el periodo federal, cada uno de los estados promulgó sus propios códigos penales, que a la postre fueron copia del código de 1837. El 26 de junio de 1873 se dicta la Ley 112 con el nuevo Código Penal de la Federación, en el cual se clasifican los delitos en 1) políticos, 2) de responsabilidad y 3) comunes o privados, en los que los políticos eran aquellos cometidos por empleados o funcionarios públicos en ejercicio de sus funciones. Este código, con base en la Constitución de 1863, eliminó las penas de muerte y todas las infamantes, y estableció límites a las corporales. ${ }^{36}$

Así, el Código en el Libro Tercero "De los delitos i culpas contra la sociedad i sus penas" contiene un capítulo denominado "Delitos contra el órden público", dentro del cual se precisa que son delitos contra el orden público: la traición a las instituciones, la rebelión, la sedición, el motin y la asonada; y que para el caso de la rebelión la pena sería de 3 a 6 años de expulsión del territorio, 0 de 2 a 4 años de prisión para los auxiliadores o colaboradores. ${ }^{37}$

33 Marco Palacios y Frank Safford. Historia de Colombia. País fragmentado, sociedad dividida. (Bogotá: Universidad de los Andes, 2013), 306.

34 Tenorio Obando, "Amnistías en Colombia: Herramienta de engaño, herramienta política y mecanismo de reconciliación", 25-26.

35 Peraza Correa, Amnistías, indultos y perdones, entre la insurrección comunera y las conversaciones de la Habana, 18

36 Cuenvo Criales, Macrocriminalidad y política de priorización en el marco de la Justicia Transicional, 242.

37 Congreso de la República. Código Penal de los Estados Unidos. Ley 112 de 1873, coordinado por 
En 1870 se propuso una reforma educativa, que tendría como consecuencia un nuevo conflicto con la jerarquía católica en torno al carácter laico o católico de la educación pública, este conflicto es aprovechado por franjas del Partido Conservador y del clero católico para desencadenar la guerra de 1876. Así, la guerra civil ocurrida entre 1876 y 1877, tuvo como fin derrocar al gobierno liberal. Ante su fracaso, la parte derrotada fue obligada al desarme y recibieron amnistía. A un sector de los rebeldes conocido como los "Mochuelos", les fue concedida la amnistía y se incorporaron varios de sus miembros a la milicia legítima ${ }^{38}$

En 1880 se celebra un tratado ante la rebelión del poeta Jorge Isaacs contra el gobierno de Pedro Restrepo Uribe en Antioquia. Resulta curioso observar que en este acuerdo se obligaron ambas partes a conferir decretos de amnistías a sus opositores. "No deben ser muchos los casos en que los jefes de un ejército revolucionario o rebelde amnistían a los miembros del gobierno legítimo". Sin embargo, esta amnistía mutua no llegó a tener efecto por la negativa del presidente Restrepo Uribe a dar cumplimiento a lo pactado. ${ }^{39}$

En 1885 se produce un levantamiento armado contra Rafael Núñez, los bandos beligerantes firman un convenio de paz. Con esta victoria, Núñez declaró "La Constitución de los Estados Unidos de Colombia ha dejado de existir", y así convocó a un Consejo Nacional de Delegatarios de los nueve estados soberanos para deliberar sobre los términos en que debería procederse a la reforma de la Constitución. ${ }^{40}$

\section{Toma de Posición}

Este periodo de la historia, desde la conquista de América, pasando por la colonización, la emancipación y la independencia, está marcado por una serie de eventos de guerras e insurrecciones, que evidencian, en primer lugar, cómo cada vez que se utilizan las armas para levantarse contra el poder de turno, se vuelven a repetir, los armisticios, los acuerdos, las pacificaciones, que terminan con la legitimación de los vencidos y el desconocimiento de los vencedores; y en segundo lugar, las guerras como una forma de hacer y entender la política en el siglo XIX, con el fin de imponer una visión y un modelo de Estado.

Con la Ley 27 de 1837 donde por primera vez se tipifica el delito político, se

Francisco Bernate y Francisco Sintura. (Universidad del Rosario, 2019), 37

38 González, Poder y violencia en Colombia, 195-196.

39 Tenorio Овando, "Amnistías en Colombia: Herramienta de engaño, herramienta política y mecanismo de reconciliación", 26-27.

40 Hernando Valencia Villa. Cartas de Batalla. (Bogotá: Panamericana, 2010), 170. 
puede evidenciar que los actos de desobediencia contra el régimen empiezan a ser criminalizados con penas severas como la pena de muerte, los trabajos forzados, el presidio, la reclusión, la infamia y la vergüenza pública; pero que con la reforma al Código Penal de 1849 y con el Código Penal de 1873 se da un giro importante a la penalización del delito político, teniendo en cuenta que se sustituyen estas penas por la expulsión del territorio nacional.

Es así como, en el siglo XIX se produjeron alrededor de 15 amnistías, cuyo objetivo era la reconciliación general, pero que como podemos observar, dentro del componente de justicia, está como contrapartida la aprobación pública por parte de los vencidos de la soberanía del vencedor, el sometimiento explícito a su orden político y la aquiescencia sobre su derecho a gobernar, recibiendo a cambio, la exención de la sanción penal.

Durante este periodo, los procesos de amnistía se caracterizaron por el sometimiento de los insurrectos a cambio de beneficios judiciales, y en este mismo sentido, hoy tenemos por ejemplo que, las penas ordinarias para los delitos cometidos durante, con ocasión o en relación directa o indirecta con el conflicto armado en la normatividad vigente se suprimieron, y en su lugar se otorgan sanciones propias, alternativas u ordinarias, dentro de un contexto de Sistema Integral, a cambio del sometimiento a un régimen de condicionalidades, que de no cumplirse, a diferencia de los procesos del siglo XIX, implicaría la pérdida de dichos beneficios. ${ }^{41}$

\section{El conflicto armado desde la regeneración conservadora}

Continuando con nuestra narrativa histórica, es necesario precisar que la Regeneración estuvo liderada por los conservadores, la iglesia y liberales derechistas, y que su inicio se puede marcar con la expedición de la Constitución de 1886, la cual consolida el centralismo, el presidencialismo, la religión oficial, el proteccionismo económico, el autoritarismo en materia de libertades públicas y el restablecimiento de la pena de muerte. ${ }^{42}$

Se expide así, la ley 19 de 1890 el nuevo Código Penal, que impone, en el artículo 170, la pena de 8 a 10 años de presidio a quienes promuevan, encabecen o dirijan una rebelión. Además, presenta los delitos que pueden ser considerados conexos, así como sus excepciones y agravaciones

41 Congreso De La República. Acto legislativo 01 de 2017.

42 Valencia Villa. Cartas de Batalla. (Bogotá: Panamericana, 2010), 165-166. 
En 1893 se produce una insurrección artesanal dirigida por el francés Marcelino Gilibert, que sacudió la capital de la república, se atacaron todas las comisarías de policía existentes en la ciudad, y en la que murieron decenas de artesanos. A esta insurrección se le bautizaría como la pueblada. Este levantamiento se produjo en señal de protesta contra un periódico oficialista que ponía en duda su conducta moral. ${ }^{43}$

Dos años después, el 15 de marzo de 1895, en Capitanejo, Santander, el general Rafael Reyes derrotó a los revolucionarios liberales levantados contra Miguel Antonio Caro. Reyes expidió salvoconductos a los vencidos. La mayoría de ellos se levantaría pocos años más tarde contra el gobierno, participando en la peor guerra de la historia de Colombia: la Guerra de los Mil Días. ${ }^{44}$

La Guerra de los Mil Días (1899-1901) evidencia las dificultades que presentaba el Estado para desarrollar el régimen centralista de la Constitución de 1886, lo mismo que los límites impuestos por la estructura de poder de las regiones, subregiones y localidades, caracterizado por relaciones gamonalicias y clientelistas. Pero la guerra también evidenció dos aspectos relevantes, el primero, la exacerbación de la reacción de los jóvenes caudillos liberales contra la exclusión del liberalismo en la representación política y el autoritarismo del conservatismo y de la iglesia católica; el segundo, que las tropas de regiones y caudillos eran ya incapaces de derrotar a un ejército nacional por débil que fuera todavía. ${ }^{45}$

Como en los procesos anteriores, tras la guerra de los mil días, se dio un intento por la paz al entender la necesidad de una gobernabilidad compartida, lo que permitió un periodo de estabilidad institucional, en el que: no se presentaron conflictos armados, se logró un nivel importante de recuperación financiera y se obtuvo la indemnización por la pérdida de Panamá. ${ }^{46}$

Para 1910, aparece un personaje que se autoproclama defensor de los indígenas; se trata del indígena "Quintin Lame", quien buscaba proteger los resguardos y recuperar las tierras perdidas por manos de los terratenientes

Manuel Quintín Lame, indígena de la hacienda de San Isidro, terrazguero de don Ignacio Muñoz en un tiempo, abandonó por el año de 1912 la vida agrícola y se dedicó

43 Renán Vega Cantor. Gente muy rebelde. Tomo 4. Socialismo, cultura y protesta popular. (Bogotá: Editorial Pensamiento Crítico), 249.

44 Peraza Correa, Amnistías, indultos y perdones, entre la insurrección comunera y las conversaciones de la Habana, 19.

45 Gonzalez, Poder y violencia en Colombia, 198

46 Tribunal Superior De Distrito Judicial. Sala de Justicia y Paz. Radicación 11001600253200680008 N.I.1821, (M.P. Alexandra Valencia Molina, 31 de octubre 2014). 
a recorrer todas las parcialidades de indígenas, aún las de las altiplanicies de Bogotá, promoviendo sigilosamente reuniones entre los indígenas con el fin de excitarlos a desconocer las autoridades y arrojar de sus tierras a los blancos para devolver a los aborígenes lo que él consideraba como territorios usurpados en época anterior, proclamándose cacique general y restaurador de la raza indígena y exigiéndoles contribuciones en dinero para llevar a cabo su obra. En Bogotá fue aprendido por la policía en 1913 y como sospechoso permaneció en el Panóptico cerca de un año, al cabo del cual fue puesto en libertad y el Director General de la Policía envió a la gobernación una filiación de Lame para que se le tuviera presente. ${ }^{47}$

Se produce entonces el levantamiento indígena en el Cauca, en donde se combinaron dos formas de lucha: la movilización y la acción jurídica legal. Su idea era crear una "República Chiquita" y liderar la lucha por la tierra, la libertad y el poder en favor de los indígenas. Realizó varias acciones armadas en distintos lugares del Cauca, y en una celada traidora tendida por políticos, en mutuo acuerdo con las autoridades, fue encarcelado durante varios meses en Neiva, acusado de los delitos de rebelión, sedición, asonada y organización de cuadrilla de malhechores. ${ }^{48}$

Quintin Lame, fue considerado por los gobiernos, tanto liberales como conservadores un "indio ignorante... promotor de una sedición encaminada a encender una guerra de razas" ${ }^{49}$

En 1919 surge el Partido Socialista, el cual participó activamente en las movilizaciones huelguísticas de 1919 y 1920, en Bogotá, Girardot, Fusagasugá. Sin embargo, el Partido es liquidado en 1924. La tierra para este periodo, se va convirtiendo, al lado de la necesidad de una reforma agraria democrática, en la razón de las luchas campesinas que atraviesan el siglo XX, e instituyen una de las causas centrales de la violencia y la guerra. ${ }^{50}$

En 1926 se fundó el Partido Socialista Revolucionario, el cual lidera las luchas reivindicativas de sectores obreros, campesinos, indígenas canalizando el descontento hacia la hegemonía Conservadora, generando en los años siguientes

47 Renán Vega Cantor. Gente muy rebelde. Tomo 2. Indígenas, campesinos y protestas agrarias. (Bogotá: Editorial Pensamiento Crítico, 2002), 40.

$48 \quad$ Ibíd., 50

49 Alfredo Molano Bravo. "Fragmentos de la historia del conflicto armado (1920-2010)", En Contribución al entendimiento del conflicto armado en Colombia, (2015), 545.

50 Carlos Medina Gallego. "Una propuesta para la periodización de la historia del conflicto colombiano en el siglo XX", En Para reescribir el siglo XX. Memoria, insurgencia, paramilitarismo y narcotráfico, coordinado por Javier Guerrero y Olga Acuña. (Bogotá: La Carreta Editores), 34. 
movilizaciones y levantamientos, de los cuales se resalta los del Líbano y Puerto Wilches. ${ }^{51}$

El 5 de diciembre de 1928, entre 2000 y 4000 huelguistas se congregaron en la estación del ferrocarril de Ciénaga, con la intención de marchar hacia Cartagena. El gobierno declaró el Estado de Sitio e impuso el toque de queda en la región. Tropas militares llegaron con la orden de dispersar a los trabajadores. A la una y media de la madrugada del 6 de diciembre, el comandante civil y militar leyó a los huelguistas el decreto de Estado de Sitio y la orden de toque de queda, y los conminó a dispersarse. Por respuesta obtuvo vivas a Colombia y a la huelga. Lo que siguió fue un baño de sangre conocido como "La Masacre de las Bananeras"52

En 1930, el liberalismo regresa al poder, en medio de la gran Depresión de los años 30, la división interna del Partido Conservador, y el periodo de movilización álgido que vivía el país. Sin embargo, con la transición política se empiezan a presentar enfrentamientos violentos en zonas tradicionalmente conservadoras, como Santander y Boyacá, en las cuales, el cambio de gobierno se convertía en una amenaza inminente para los poderes locales consolidados, teniendo como consecuencia el germinar del ánimo vengativo y la disputa entre los dos partidos. ${ }^{53}$

Producido el primer ataque sangriento de liberales contra conservadores, 0 viceversa, queda urdida la cadena de la violencia que después sería imposible romper. ${ }^{54}$

Apenas transcurre día sin que los periódicos den cuenta de un crimen horrendo. Lo más doloroso es que la sociedad parece haberse familiarizado con la producción en serie del crimen. Nadie se impresiona ante el atentado criminal. Asesinatos en que los bandidos ultiman familias enteras, ancianos y niños; venganzas que recuerdan la vendetta corsa; actos de crueldad estúpida como desollar a las víctimas y mutilarlas en forma salvaje; asesinatos de sacerdotes octogenarios, para robarlos; el puñal y el revólver usados en reyertas por centavos; el atraco en pleno día en las calles de la capital; la inseguridad en las ciudades y en los campos. Tal es el cuadro. ${ }^{55}$

51 Vega Cantor, Gente muy rebelde. Tomo 4. Socialismo, cultura y protesta popular, 245

52 Marco Palacios y Frank Safford. Historia de Colombia. País fragmentado, sociedad dividida. (Bogotá: Universidad de los Andes, 2013), 407.

53 Gonzalez, Poder y violencia en Colombia, 251-252.

54 German Guzmán, Orlando Fals Borda, y Eduardo Umaña Luna. La violencia en Colombia. Tomo 1. (Bogotá: Panamericana), 25.

55 Ibíd., 24. Descripción de Colombia en 1934 elaborada por Max Grillo, destacado político liberal. 
El 24 de abril de 1936 se expide el nuevo Código Penal, que entró en vigencia desde el 1 de julio de 1938, inspirado en el Código italiano de Rocco. Sus redactores explican que siguiendo los principios de la defensa social, adoptan la actividad sicofísica como base de la imputabilidad, así, los locos, anormales, intoxicados, menores, entre otros, en su condición de peligrosos quedan sometidos a la ley penal, por lo cual el juez, al aplicar una sanción, requiere estudiar la personalidad del delincuente, los motivos determinantes de su actuar y las circunstancias de mayor o menor peligrosidad que le caracterizan; las sanciones por consiguiente han de ser penas y medidas de seguridad. ${ }^{56}$

El Código Penal de 1936, paradójicamente disminuyó notablemente las penas contempladas para los delitos políticos en el Código de 1890, acogiendo la tesis, de que los delincuentes políticos sociales, por las metas altruistas que persiguen, no son temibles para la sociedad. ${ }^{57}$

La definición del delito de rebelión en la Ley 95 de 1936, señaló en su artículo 139:

[...] alzamiento en armas para derrocar al gobierno nacional, legalmente constituido, o para cambiar o suspender en todo 0 en parte el régimen constitucional existente, en lo que se refiera a la formación, funcionamiento o renovación de los poderes públicos u órganos de la soberanía, están sujetos a prisión de seis meses a cuatro años.

A pesar de ser un código de corte peligrosista, el artículo 142 estipuló que:

Los rebeldes no quedarán sujetosaresponsabilidad por las muertes o lesiones causadas en el acto de un combate; pero el homicidio cometido fuera de la refriega, el incendio, el saqueo, el envenenamiento de fuentes o depósitos de agua, y en general los actos de ferocidad o barbarie, darán lugar a las sanciones respectivas, aplicadas acumulativamente con las de rebelión. ${ }^{58}$

Los conservadores, entre ellos Laureano Gómez, atacaban en plaza pública, por radio y desde periódicos como El Siglo, al liberalismo y al comunismo, no ocultando su simpatía hacia la Alemania Nazi y los fascistas italianos. En 1946, en medio de

56 Carlos Salazar Cáceres. "Breve historia del derecho penal colombiano", Revista Principia luris, 13, n $26,48$.

57 Carlos Gaviria Díaz. Sentencias Herejías Constitucionales. (Bogotá: Fondo de Cultura Económico, 2002), 306.

58 Cuenvo Criales, Macrocriminalidad y política de priorización en el marco de la Justicia Transicional, 245-246. 
la división del Partido Liberal, asume la presidencia el conservador Mariano Ospina, bajo el discurso político de la unidad nacional, la concordia y la paz, sin embargo, en este periodo se agudizan las matanzas y las persecuciones contra liberales y gaitanistas en distintas regiones del país. ${ }^{59}$

La violencia contra el gaitanismo era un hecho desde 1944, Gaitán denuncia en 1947, a través del periódico Tribuna Liberal, la barbarie que se presentaba en municipios de los departamentos de Nariño, Boyacá, Tolima, Norte de Santander, Bolívar, Caldas, entre otros, solicitando al presidente Ospina, ayudar a detener la violencia. ${ }^{60}$

En este periodo también se organizan cuadrillas conservadoras que actuaban como defensoras de la restauración conservadora, tal es el caso de la vereda Chulavita de Boavita, Boyacá, por su gentilicio se les conocería como "chulavitas", que con las policías departamentales y municipales, asolarían el país. ${ }^{61}$

En 1948 se inflama cada vez más el país, motines y saqueos en Cali, huelgas en Bogotá, ataques al ejército en Norte de Santander, incendios en aldeas liberales, atentados dinamiteros contra el gerente de la Tropical Oil Company, sabotaje a líneas férreas. El 7 de febrero, Gaitán organizó la célebre "Marcha del Silencio", en donde denunció la matazón de campesinos liberales. Cien mil ciudadanos llenaron la Plaza de Bolívar. ${ }^{62}$

El 9 de abril cae asesinado Gaitán, se producen levantamientos espontáneos, protestas y formación de juntas provisionales de gobierno, en diversos lugares del país, alcanzando una dimensión nacional, tanto a nivel urbano como en zonas rurales. ${ }^{63}$ José María Villareal siendo gobernador de Boyacá, armó y transportó 200 civiles armados de la vereda Chulavita hacia Bogotá el 10 de abril. ${ }^{64}$

Entre las repercusiones del 9 de abril cabe destacar cuatro elementos relevantes para el porvenir de la historia colombiana. El primero, la adopción del anticomunismo como doctrina oficial del gobierno colombiano, en concordancia con lo acordado en la Conferencia Panamericana; el segundo efecto fue la reorganización de los cuerpos militares del estado colombiano; el tercero resultaría ser la participación protagónica de muchos "nueveabrileños" en gestas de resistencia contra la violencia oficial, entre otras, a través de baluartes guerrilleros; y en cuarto lugar, la violencia

59 Molano Bravo, "Fragmentos de la historia del conflicto armado (1920-2010)", 548.

60 Guzmán, Fals Borda, y Umaña Luna, La violencia en Colombia, 27.

61 Renán Vega Cantor y Eduardo Rodríguez. Economía y violencia. (Bogotá: Fondo de Publicaciones de la Universidad Distrital Francisco José de Caldas, 1990), 5.

62 Guzmán, Fals Borda, y Umaña Luna, La violencia en Colombia, 31.

63 Vega Cantor y Rodríguez, Economía y violencia, 7.

64 Molano Bravo, "Fragmentos de la historia del conflicto armado (1920-2010)", 548. 
se desplaza definitivamente de las ciudades al campo. ${ }^{65}$

El 27 de octubre de 1949 es asaltado, incendiado y saqueado el caserío de Ceilán en Bugalagrande, Valle del Cauca, donde los bandidos dejan cerca de 150 víctimas, algunas de ellas incineradas. En seguida, masacran en San Rafael a 27 ciudadanos cuyos cadáveres arrojados al río empurpuraron las aguas. ${ }^{66}$

Escribe Antonio García, en el prólogo de la novela Viento Seco:

Hay quien pregunta ¿Por qué se ha perdido el valor de la vida humana?

Estamos cosechando la única siempre que han hecho nuestros partidos históricos: en esta sangre derramada, en estos delitos infamantes, en esta crueldad sin castigo, se resume el sentido de nuestra historia partidista. Los verdaderos responsables de este derrumbamiento no son los delincuentes vulgares: es el sistema político que los toma como sus instrumentos, como sus órganos de dominio, que los alienta, que los estimula, que los remunera, que los premia.

Los intelectuales, las élites, los grupos dirigentes son responsables de esta degradación multitudinaria, de esta renovada mutilación de todos los hombres humildes... Son responsables por su cobardía, por su egoísmo, por su estrechez moral, por su noción deforme de la patria... Todos somos responsables, todos estamos viviendo -conformes, cristianos, fríos, monstruosamente tranquilos- sobre esta herencia de sangre. ${ }^{67}$

Pedro Antonio Marín se crio y creció en Ceilán, de donde huyó en 1948, cuenta lo siguiente en los libros de Trochas y fusiles de Alfredo Molano, y las muertes de Tirofijo de Arturo Alape:

Cuando parecía que se calmaba la matazón del puente de San Rafael que dejó varios días, rojo el río, una tarde se desató un aguacero de balas. De las esquinas del pueblo, del atrio, de la torre, del techo de la alcaldía, de todos lados salía plomo. Los vecinos corrían de un lado para otro, la guardia cívica disparó 80 tiros, los que tenían, y todo el mundo echó para el monte. Hasta los tullidos corrían.

Masacraron a todo el mundo, porque le metieron policía, pájaros, ejército,

65 Vega Cantor y Rodríguez, Economía y violencia, 13-16.

66 Guzmán, Fals Borda y Umaña Luna, La violencia en Colombia, 31.

67 Daniel Caicedo. Viento Seco. (1954), 15-43. 
totalmente equipados, y destruyeron todo a su paso, quemaron todo; mejor dicho, lo que uno sabe es que les dieron muerte por lo menos a 300 liberales. Luego fue la desbandada de la resistencia. ${ }^{68}$

Posteriormente, luego del golpe de estado contra Laureano Gómez, y con la llegada de Rojas Pinilla, se recrudece la lucha armada, surgen nuevos actores, las autodefensas que protegían a la población civil del ejército y la policía. Igualmente, surgen las guerrillas liberales, entre las que se cuentan las de Juan de Jesús Franco, en la región de Urrao; los frentes de Eduardo Franco y Guadalupe Salcedo en los Ilanos orientales; las limpias o liberales de Gerardo Loaiza y las comunes o comunistas de Jacobo Prías Alape ${ }^{69}$, en el sur del Tolima. No obstante, las guerrillas terminarían combatiendo entre sí, las comunes establecieron contactos con focos agraristas del Sumapaz, encabezados por Juan de la Cruz Varela. ${ }^{70}$

En razón a esta situación, Rojas Pinilla inicia entonces un nuevo proceso de pacificación, en el cual se presenta dejación de armas, indultos parciales para presos políticos -Decreto 1546 de junio 22 de 1953- y amnistías generales -Decreto 2184 de agosto 21 de 1953. Guadalupe Salcedo, aceptó la entrega de armas, y visitó los comandos para consultar la decisión. Acordaron la entrega a cambio de garantías políticas para el liberalismo, la reconstrucción de pueblos, organización de cooperativas y titulación de 100 hectáreas a cada una de las 1500 familias afectadas. ${ }^{11}$

Con la entrega de armas, a renglón seguido, serían asesinados la mayoría de las comandantes desmovilizados, y fortalecidas las guerrillas de paz, compuesta por sectores afines al gobierno, es decir, una contraguerrilla. Ante las ambigüedades del proceso de pacificación, tanto liberales como comunistas reanudaron la lucha guerrillera.

Para conmemorar el primer año de su mandato Rojas Pinilla, expidió el Decreto-

68 Molano Bravo, "Fragmentos de la historia del conflicto armado (1920-2010)", 559.

69 Es importante destacar el papel que va a tener Jacobo Prías Alape "Charro Negro" durante este periodo, así como el impacto que va a tener su asesinato para "Manuel Marulanda". "el asesinato se enmarcaba en las rivalidades entre los distintos grupos que eran utilizados por los gobiernos departamentales para la lucha contra el abigeato y la inseguridad generalizados. Esto hacía que cada grupo culpara al otro de los robos de ganado, y supuestamente el crimen se produjo cuando una patrulla de "Mariachi", penetró la zona comunista de Gaitania en busca de unas reses robadas en el Cauca. Esto llevó a "Charro Negro" a reclamar por el incidente y fue asesinado en ese altercado, acto que desató un combate general entre las gentes de "Mariachi", Isauro Yosa y "Tiro Fijo".

70 Marco Palacios y Frank Safford. Historia de Colombia. País fragmentado, sociedad dividida, (Bogotá: Universidad de los Andes, 2012), 500.

71 González, Poder y violencia en Colombia, 308-309. 
ley 1823 de junio de 1954, por medio del cual otorgó amnistía para delitos políticos cometidos antes del 1 de enero de 1954, entendiendo el delito político como cualquier ataque dirigido contra el gobierno, así como rebajas de pena para los comunes, sujetos únicamente a la condición de entregar las armas. ${ }^{72}$

A fines de 1955 Rojas empezó a perder respaldo de los partidos tradicionales, por la relación Pueblo - Fuerzas Armadas que planteó, también por la construcción de una base política y un movimiento político propio, así como la ineficacia para aplacar la Violencia, factores que llevaron a que los partidos acordaran en España la división del poder de forma pacífica mediante el llamado Frente Nacional. ${ }^{73}$

Por primera vez, mediante decreto 0942 del 27 de mayo de 1958 se dio origen a la Comisión Nacional Investigadora de las Causas Actuales de la Violencia. La comisión visitó poblados, villorrios, zonas devastadas, por atajos y riscos.

Es la primera vez, decían los campesinos, que vienen a preguntarnos qué nos pasó; a conversar con nosotros sin engaño; a hablarnos de paz sin echarnos bala después: La Comisión hubo de buscar un verdadero cese de fuego a través de convenios, manifiestos y entrevistas. Así, pudo lograrse en total 52 pactos de paz, habiéndose realizado cerca de 20.000 entrevistas personales, sin contar los contactos con agrupaciones en pueblos y veredas. $^{74}$

El Frente Nacional surgía en un contexto internacional complejo, la Revolución Cubana de 1959 y la bipolaridad entre bloques socialistas y capitalistas en todo el mundo. Desde un inicio, se implementan políticas contrainsurgentes apoyadas por el gobierno de los Estados Unidos, que no impidieron la creación de las guerrillas de las FARC, el Ejército de Liberación Nacional (ELN), el Ejército Popular de Liberación (EPL), entre otras insurgencias.

El gobierno de Lleras Camargo (1958-1962), lleva a cabo dos estrategias para afrontar la situación que atravesaba el país, por un lado, le dio origen a la Comisión Especial de Rehabilitación, la cual pretendía generar soluciones al fenómeno de la violencia a través de la construcción de escuelas, programas asistencialistas, y obras públicas, junto a esta estrategia social-humanitaria, se decretaría amnistía e indulto, mediante Decreto 328 del 28 de noviembre de 1958, en algunos departamentos por delitos que hubieran tenido causa en las confrontaciones políticas partidistas. ${ }^{75}$

72 Tenorio Obando, "Amnistías en Colombia: Herramienta de engaño, herramienta política y mecanismo de reconciliación", 35.

73 BushnelL, Colombia una nación a pesar de sí misma, 314.

74 Guzmán, Fals Borda, y Umaña Luna, La violencia en Colombia, 99.

75 Molano Bravo, "Fragmentos de la historia del conflicto armado (1920-2010)", 559. 
La política de injerencia norteamericana, conlleva a que Lleras solicite el apoyo a la Central de Inteligencia Americana (CIA), materializado en un informe de 1960, en el cual se advierte el potencial peligro del comunismo, se aconseja una fuerza móvil contrainsurgente, al tiempo, reformas sociales, políticas y económicas. Forma parte del mismo proceso, el conocido Plan Laso de 1964, que desarrollaría operaciones militares en las denominadas "Repúblicas Independientes" contra las autodefensas, que a raíz de los ataques desproporcionados recibidos por parte de la fuerza pública, pasarían a organizarse como una guerrilla comunista y agraria denominada Fuerzas Armadas Revolucionarias de Colombia. ${ }^{76}$

Bajo la administración de Lleras Restrepo (1966-1970), se expidió el decreto 2090 de 1967 que amnistiaba e indultaba a los estudiantes y sindicalistas, que se movilizaban y protestaban. Sin embargo, con este decreto se confiere amnistía a miembros de la fuerza pública implicados en los homicidios y torturas a estudiantes en octubre de 1966 y junio de 1967, en consecuencia, se institucionaliza el crimen por parte del Estado. ${ }^{77}$

La ley 48 de 1968 abre las puertas a la privatización de la lucha contrainsurgente y a la autonomía clandestina de sectores radicales de las fuerzas armadas, a la represión de la protesta social, a la adopción del Estatuto de Seguridad, y a la promoción a finales de los años setenta de los grupos llamados de autodefensa con la ayuda del ejército en armas, municiones, entrenamiento y respaldo en sus operaciones. ${ }^{78}$

\section{Toma de Posición}

Este periodo, que comprende la Hegemonía Conservadora, la República Liberal, el gobierno militar de Rojas Pinilla y el inicio del Frente Nacional, se ve atravesado por una serie de factores:

En primer lugar, la forma de hacer la guerra del siglo XIX acaba con la Guerra de los Mil Días, para dar paso a la búsqueda de la consolidación de un Estado republicano y la necesidad de consensos entre las clases dominantes regionales, lo que posibilitaría el surgimiento de más actores en la esfera política nacional, tal es el caso de Quintín Lame, o el surgimiento de un tercer partido político, el Partido Socialista Revolucionario, los cuales abrirían paso a luchas reivindicativas de indígenas, obreros, estudiantes, entre otros.

76 Víctor Manuel Moncayo. "Hacia la verdad del conflicto: Insurgencia guerrillera y orden social vigente", en Contribución al entendimiento del conflicto armado en Colombia, (2015), 118.

77 Tenorio Obando, "Amnistías en Colombia: Herramienta de engaño, herramienta política y mecanismo de reconciliación", 37.

78 MoncaYo, "Hacia la verdad del conflicto: Insurgencia guerrillera y orden social vigente", 118. 
En segundo lugar, con la Constitución de 1886 se instaura nuevamente la pena capital para los delitos políticos, que es eliminada con el Acto Legislativo No. 3 de 1910, y que finalmente adquiere un nuevo matiz con la expedición del Código Penal de 1936, al otorgar un tratamiento especial al delito político, reconociendo los fines altruistas que persigue.

En tercer lugar, las amnistías en este periodo cumplen con un fin similar al descrito en el capítulo anterior, buscar que el bando que se alza contra el régimen constitucional les otorgue beneficios judiciales, pero además de esto, que se les brinde apoyo para salir de situaciones de pobreza, exclusión o marginalidad; sin embargo, los resultados obtenidos solo se refieren a la dejación de las armas y al otorgamiento de amnistías sin ningún tipo de cambio social, económico o político, que beneficie a los sectores menos favorecidos.

Un ejemplo destacado de este periodo es el que refiere a la amnistía a Guadalupe Salcedo en 1953, en el cual, si bien hubo un desarme y le fue concedida la amnistía, con el fin de no ser condenado penalmente, el Estado no cumplió y finalmente fue asesinado, como trescientos años antes sucedió con Benkos Bioho, entre muchos otros. La diferencia es que, aquí ya se ha consolidado normativamente los tipos penales contra el régimen constitucional y legal, con un carácter altruista; pero pese a ello, los resultados siguen siendo los mismos.

Por último, cabe destacar que en este periodo surgen iniciativas como la Comisión Nacional Investigadora de las Causas Actuales de la Violencia y la Comisión Especial de Rehabilitación, las cuales permiten concluir que desde aquel momento se resalta la importancia de entender el porqué del conflicto, buscando encontrar verdad y dar solución a causas que originaron el mismo. Sin embargo, todo esto fracasaría, justamente por el incumplimiento del Estado, que generaría nuevas formas de levantamiento en armas.

\section{La rebelión de los grupos insurgentes}

Este punto de inflexión de la historia de Colombia, nuevamente se presenta en medio de incumplimientos por parte del Estado colombiano a los sectores que se movilizaron en las décadas anteriores, y que exigían reformas en la cuestión agraria, en la participación política, entre otras reivindicaciones.

Las tradiciones de las luchas guerrilleras de la Violencia de los años cincuenta se combinan con la radicalización de grupos jóvenes urbanos que, influidos por los procesos revolucionarios y el pensamiento marxista, no encuentran canales 
de representación en la estructura tradicional de los partidos, contribuyendo al imaginario rebelde y una opción por la lucha armada. Así surgirían, las FARC, el ELN y el EPL en la década del $60 .{ }^{79}$

En adelante muchos otros grupos guerrilleros se organizan en las décadas del 70 y 80, las Auto-Defensa-Obrera-AD0, el Movimiento Armado Indígena Quintin Lame, el Ejército Revolucionario Guevarista (ERG), el Partido Revolucionario de los Trabajadores (PRT), el Ejército Revolucionario Independiente de la Costa Atlántica (ERICA), el Frente Ricardo Franco, el Comando Armado del Pueblo, y otros más. ${ }^{80}$

Fals Borda, analiza la subversión y resalta que esta se le designa como algo inmoral, sin embargo, se olvida que muchos subversores no pretenden "destruir" la sociedad porque sí, como un acto ciego y soberbio, sino más bien reconstruirla según novedosas ideas y siguiendo determinados ideales o utopías que no acoge la tradición. El análisis de las experiencias latinoamericanas prueba que muchas transformaciones significativas y profundas de la sociedad han sido posibles por la acción subversiva y el pensamiento rebelde. ${ }^{81}$

En complemento de lo anterior, los movimientos insurgentes requieren de un entendimiento que trascienda la criminalización clásica, para esto resulta importante las proposiciones que presenta Víctor Manuel Moncayo, estas son:

a). En todas las sociedades contemporáneas, existen relaciones contradictoras, conflictivas, frente a las cuales se presentan resistencias de dos tipos: la primera, "normal" o "civilizada", permitida por el Estado para que se actúe conforme a las reglas del sistema. La segunda, rompe la "normalidad", en las que incluso se puede desconocer el monopolio estatal legítimo de la fuerza, asumiendo como legítima la utilización de la violencia.

b). El proceso subversivo, como expresión de resistencia al orden existente con la pretensión de sustituirlo, es inherente a toda sociedad.

c). En la historia de Colombia, las resistencias han transitado por la ruptura de la "normalidad", en primer lugar por el problema agrario, y luego como vía de resistencia con el propósito de transformar la sociedad. No obstante, este proceso se ha alterado por la intervención de otros factores derivados

79 González, Poder y violencia en Colombia.

80 Tribunal Superior De Distrito Judicial. Sala de Justicia y Paz. Radicación 11001600253200680008 N.I.1821. (M.P. Alexandra Valencia Molina, 31 de octubre 2014).

81 Orlando Fals Borda. Una sociología sentipensante para América Latina. (México D.F: Siglo XXI, 2015), 390. 
de la economía de los narcóticos y del paramilitarismo, que transformaron el accionar de la subversión armada.

d). La circunstancia de violencia ha estado presenta casi a todo lo largo de la existencia de la sociedad colombiana. Durante el siglo XIX Colombia vivió ocho guerras civiles generales, catorce locales y dos guerras con el Ecuador, en el siglo XX tuvo la guerra con Perú, numerosos levantamientos populares urbanos y rurales, la violencia bipartidista de los cuarenta y cincuenta, y la contemporánea que enlaza de manera compleja las organizaciones guerrilleras, los paramilitares, los carteles y las agrupaciones de la economía de los narcóticos, y la acción militar y policiva del Estado, con el apoyo económico y técnico de los Estados Unidos. ${ }^{82}$

En paralelo a la insurgencia, surge la contrainsurgencia como mecanismo de defensa del sistema, cimentado a partir de la doctrina de seguridad nacional, surge el paramilitarismo por vía legal: decreto 3398 de 1965 destinado a organizar la defensa nacional como respuesta al surgimiento de los grupos subversivos, adoptado como legislación permanente por la Ley 48 de 1968, en la que se propugnaba por "unir a las fuerzas vivas de la nación" para enfrentar la acción subversiva de grupos extremistas. ${ }^{83}$

Los artículos 25 y 33 del Decreto Legislativo 3398 de 1965, concluyó la Corte Interamericana de Derechos Humanos en el caso 19 Comerciantes vs Colombia, prohijaron la aparición de los llamados Grupos de Autodefensa, en tanto que se permitía al gobierno nacional utilizar ciudadanos no comprendidos en el llamamiento al servicio militar obligatorio, en actividades tendientes a restablecer la normalidad, así como, facultar al Ministerio de Defensa para amparar como de propiedad particular, cuando lo estimara conveniente, armas consideradas como de uso de las Fuerzas Armadas. ${ }^{84}$

Se puede concluir, a partir de lo anterior, que el Estado y sus fuerzas militares tuvieron una participación activa en la organización y despliegue del paramilitarismo, tal y como ha quedado señalado en las sentencias de Justicia y Paz.

82 Moncayo, "Hacia la verdad del conflicto: Insurgencia guerrillera y orden social vigente", 111.

83 Corte Suprema de Justicia. Sala de Casación Penal. Segunda Instancia 34547, Sentencia Cobos y Banquez. (27 de abril de 2011). lbíd., 3 
El paramilitarismo tuvo un crecimiento exponencial, en su momento se estimó en cerca de 20.000 militantes, adquirió poderosa capacidad bélica, a partir de fuentes de financiación tales como el apoyo económico de los agentes económicos ligados al sector rural, el cobro de impuestos a la actividad económica legal e ilegal, la participación directa en la producción y comercio de sustancias ilícitas, y la desviación de recursos públicos gracias al control que ejercían en administraciones de entidades territoriales. Su función resulta ser, defender a sangre y fuego el statu quo. ${ }^{85}$

El paramilitarismo, bajo su lógica antisubversiva, de pacificación y de terror, recrudece las masacres en todo el país, lo que tendría como consecuencia un masivo desplazamiento de campesinos y poblaciones étnicas a las periferias de ciudades como Bogotá, Cali o Medellín.

\section{Toma de Posición}

Si bien, con la entrada en vigencia del Código Penal de 1936, se estructura normativamente el delito político como una violación al régimen constitucional y legal, con el reconocimiento de una finalidad altruista, lo cierto es que, durante el surgimiento de las insurgencias, dicha finalidad no fue tenida en cuenta, toda vez que a los levantados en armas no se les reconoció el estatus de delincuentes políticos, sino como delincuencia organizada, y su tratamiento resulto ser por la vía militar, como sucedió en Marquetalia con las FARC y Anorí con el ELN.

Este periodo es determinante para la consolidación del fenómeno político de los delitos políticos en Colombia, en tanto que se crearon, organizaron y se fortalecieron estructuralmente insurgencias con objetivos claros de modificar o derrocar al régimen vigente.

Sin embargo, se puede constatar que la respuesta del Estado para contrarrestar los grupos insurgentes resulto ser, la lucha contrainsurgente de las Fuerzas Militares en alianza con los Estados Unidos. Así mismo, se presenta la creación de grupos de paramilitares en diferentes regiones del país, apoyados por los hoy denominados "terceros civiles", políticos, empresarios, ganaderos, latifundistas, entre otros, que con su accionar de "pacificación" traerían consigo despojo, masacres, desplazamiento y miedo a la población civil.

85 MoncaYo, "Hacia la verdad del conflicto: Insurgencia guerrillera y orden social vigente", 111. 


\section{Aproximaciones a los procesos de paz}

En el marco de la convulsionada ola de protestas, movilizaciones, paros y expansión de movimientos insurgentes, se gesta un creciente proceso de persecución, criminalización y judicialización de la protesta social, el caso que mejor ilustra esta situación, es la expedición del Decreto 1923 de 1978, mejor conocido como Estatuto de Seguridad, durante el gobierno de Turbay, el cual aumentaba las penas para varios delitos ${ }^{86}$, extendía la categoría de subversión para quienes incitaran a la revuelta o a la desobediencia a las autoridades, la fijación de las penas por estos delitos era atribuida a autoridades militares, policiales y civiles. De igual forma, se empleaban métodos de tortura y tratos crueles e inhumanos. ${ }^{87}$

El conflicto para este periodo presentaría un progresivo proceso de degradación, en tanto que, fue notorio el aumento de capacidad militar del paramilitarismo, de los carteles del narcotráfico, y de la insurgencia. Esto, iba en conjunto con el aumento progresivo de las masacres, asesinatos selectivos, genocidios, desapariciones, desplazamientos masivos de población, es decir, un estado de crisis humanitaria, que de igual forma permitiría plantear la necesidad de una solución política del conflicto armado.

Con la expedición del Decreto ley 100 de 1980 se promulga un nuevo Código Penal, en el que continúa el trato benigno o diferencial al delito político, en el artículo 127 se enuncia que:

Artículo 127. Exclusión de pena. Los rebeldes o sediciosos no quedarán sujetos a pena por los hechos punibles cometidos en combate, siempre que no constituyan actos de ferocidad, barbarie 0 terrorismo. ${ }^{88}$

Se incluyen también dentro de las categorías de delitos políticos la conspiración en el artículo 130 "Los que se pongan de acuerdo para cometer delito de rebelión 0 de sedición, incurrirán, por este solo hecho, en arresto de cuatro meses a dos años"; y la Seducción, usurpación y retención ilegal de mando.

El que, con el propósito de cometer delito de rebelión o de sedición, sedujere personal de las Fuerzas Armadas, usurpare mando militar o policial, o retuviere ilegalmente mando político, militar o policial, incurrirá en prisión de cuatro meses a dos años.

87 González, Poder y violencia en Colombia, 371-376.

88 Declarado inexequible en la Sentencia C-456 de 1997 por la Corte Constitucional. 
El 23 de marzo de 1981, mediante la Ley 37, se concede amnistía a los autores o partícipes de hechos que constituyeran rebelión, sedición 0 asonada, y delitos conexos de los anteriores excluyendo el secuestro, la extorsión, el homicidio cometido fuera de combate, el incendio, el envenenamiento de fuentes o depósitos de agua $y$, en general, los actos de ferocidad o barbarie, cometidos antes de su entrada en vigencia y por un término de cuatro meses después de dicha entrada en vigencia, aclarando que quienes se encontraran detenidos o condenados por los delitos objeto de la ley, podrían solicitar la amnistía. ${ }^{89}$

Pese a lo anterior, las amnistías para los insurgentes son recibidas con escepticismo, teniendo en cuenta lo que había acontecido en otros procesos de rendición, dejación 0 entrega de armas..$^{90}$

El gobierno de Betancur retoma la idea de la Comisión de Paz, la constituye a través del decreto 2771 del 19 de septiembre de 1982, junto a esto se expide una nueva ley de amnistía, ley 35 del 19 de noviembre de 1982, que otorgaba este beneficio a los autores, cómplices y encubridores de hechos constitutivos de delitos políticos y los conexos a este, salvo el homicidio fuera de combate ejecutado con sevicia o colocando a la víctima en estado de indefensión. ${ }^{91}$

La búsqueda de una salida negociada al conflicto tendría un momento histórico, Betancur le propone a las FARC la creación de una organización pacífica que permitiera la progresiva inserción de los alzados en armas a la sociedad civil. Antes de diciembre de 1983, las FARC en rueda de prensa anuncian su decisión unilateral de aceptar el cese al fuego, firmar la tregua y sentar las bases para la creación de un movimiento legal. El 28 de marzo de 1984 se firma el Acuerdo de la Uribe. ${ }^{92}$

Este Acuerdo contemplaba la creación de una Comisión Nacional de Verificación, la acogida a los beneficios contemplados en la ley de amnistía, la condena pública del secuestro y la extorsión como formas de lucha revolucionaria, y la ratificación del perdón y el olvido como condiciones para el establecimiento de la paz. En este mismo contexto, Betancur también logró un acuerdo de Cese al fuego y de participación en

89 Cuervo Criales, Macrocriminalidad y política de priorización en el marco de la Justicia Transicional, 300.

90 Jacobo Arenas mencionaba que, suponiendo que se aprobara la ley de amnistía, la ley dirá: entréguense y entreguen las armas, eso ya aconteció varias veces en Colombia, y luego van cayendo los luchadores uno tras otro. "Usted sabe cómo cayó Guadalupe Salcedo? ¿Cómo han caído miles de combatientes luego que ingenuamente entregaron sus armas". Carlos Medina Gallego. FARC-EP, Notas para una historia política 1958-2006. (Centro de Documentación de los Movimientos Armados), 134.

91 Ibíd., 301.

92 Correa Peraza, Amnistías, indultos y perdones. Entre la insurrección comunera y las conversaciones de La Habana, 31-34. 
un gran dialogo nacional con las insurgencias del M-19 y el EPL. ${ }^{93}$

El 4 de junio de 1985 se aprobó la ley de indulto, mediante la cual se autorizó al Presidente para que concediera indultos a los condenados mediante sentencia ejecutoriada por los delitos de rebelión, sedición y asonada. Indulto extensible a los delitos conexos con los anteriores. ${ }^{94}$

Sin embargo, el escenario institucional para aprobar las reformas acordadas se desarrollaba con lentitud, sumado con la negación de las Fuerzas Militares de aceptar lo acordado, las constantes violaciones a la tregua pactada, y el asesinato de líderes del nuevo partido "Unión Patriótica", conllevarían a que las insurgencias desarrollaran acciones como la Toma del Palacio de Justicia en 1985 por parte del M-19, el comienzo del fin de la paz ofrecida por Betancur. ${ }^{95}$

De este periodo resulta importante tener en cuenta que, la lógica de construcción de paz se centró en los bandos firmantes, no hubo un escenario de apropiación social, ni de incorporación de otros actores relevantes en las discusiones políticas para la solución del conflicto; en las regiones, los poderes locales continuaron sus alianzas con sectores paramilitares. El resultado de esto es que se desencadenaría un genocidio en contra de los militantes de la UP, así como de militantes de otros partidos como A luchar o Esperanza, paz y libertad.

Con la llegada a la presidencia de Virgilio Barco en 1986, se intenta firmar nuevamente acuerdos con las insurgencias, que lograron generar un escenario de coordinación denominado la Coordinadora Guerrillera Simón Bolívar. En este periodo también se presenta el asesinato de cuatro candidatos presidenciales.

De igual forma se efectuó la creación de la Consejería Presidencial de Paz, y se elaboró un proyecto de indulto, cuya aplicación estaba sujeta a la verificación de la desmovilización y dejación de armas. Se suscribiría así el "Acuerdo político entre el Gobierno Nacional, los Partidos Políticos, el M19 y la Iglesia Católica en calidad de tutora moral y espiritual del proceso" el 2 de noviembre de 1989.

La Ley 77 del 22 de diciembre de 1989 facultó al presidente para conceder indultos a los nacionales colombianos con las siguientes reglas:

1. El indulto beneficiará a los nacionales colombianos, autores 0 cómplices de hechos constitutivos de delitos políticos, cometidos antes del 22 de diciembre de 1989

93 ReYes, Yesid, "Colombia entre la guerra y la paz", cit., p. 76

94 Correa Peraza, Hernando, Amnistías, indultos y perdones. Entre la insurrección comunera y las conversaciones de La Habana, cit., p. 36

95 REYES, "Colombia entre la guerra y la paz", 77. 
2. Se concederá cuando a juicio del Gobierno Nacional la organización rebelde haya demostrado inequívocamente su voluntad de reincorporarse a la vida civil, lo cual implica la dejación de armas.

3. El indulto no se aplicará a los homicidios cometidos fuera de combate, con sevicia, o colocando a la víctima en estado de indefensión, ni a los actos de ferocidad o barbarie y tampoco a quienes forman parte de organizaciones terroristas

4. Se concederá el indulto mediante cesación de procedimiento a quienes estén siendo procesados por estos delitos, por decisión inhibitoria a quienes se les vaya a iniciar procesos en virtud de esta ley y la libertad a quienes estuvieran privados de la libertad por razón de estos. ${ }^{96}$

El gobierno de Cesar Gaviria, suscribió además, acuerdos con otras insurgencias como el Partido Revolucionario de los Trabajadores (PRT), con el EPL, y con el Movimiento Armado Quintin Lame (MAQL), delimitados a través del Decreto 213 de enero de 1991. Con la Corriente de Renovación Socialista del ELN, por medio de la expedición de otra ley de indulto, Ley 104 de 1993.

El sistema, luego de múltiples intentos fracasados, logra adoptar la nueva Constitución de 1991, presentada como un ingrediente del proceso de paz con las organizaciones guerrilleras, la cual presenta una amplia renovación de los derechos fundamentales, así como, principios y reglas nuevas acordes con las transformaciones del sistema capitalista mundial, ligadas con la redefinición de la misión del Estado bajo el predominio de la economía de mercado. ${ }^{97}$

En el marco de esta constitución, se relaciona el delito político en los siguientes artículos:

Artículo 35. Se prohíbe la extradición de colombianos por nacimiento. No se concederá la extradición de extranjeros por delitos políticos o de opinión.

Artículo 150. Corresponde al Congreso hacer las leyes. Por medio de ellas ejerce las siguientes funciones [...]

17. Conceder, por mayoría de los dos tercios de los votos de los miembros de una y otra cámara y por graves motivos de conveniencia pública,

96 Cuervo Criales, Macrocriminalidad y política de priorización en el marco de la Justicia Transicional, 301.

97 MoncaYo, “Hacia la verdad del conflicto: Insurgencia guerrillera y orden social vigente”, 151. 
amnistías o indultos generales por delitos políticos

Artículo 201. Corresponde al Gobierno, en relación con la Rama Judicial: [...]

2. Conceder indultos por delitos políticos, con arreglo a la ley, e informar al Congreso sobre el ejercicio de esta facultad.

De la lectura de estos artículos, se puede evidenciar que el Constituyente continúa con la lógica del trato diferenciado y más benigno del delito político. ${ }^{98}$

Con Samper, se expide el decreto 104 de 1996, que permitió al ejecutivo suspender la ejecución de cualquier orden de captura para el desplazamiento de representantes de grupos guerrilleros para adelantar negociaciones con el gobierno.

El auge neoliberal se erige como una causa acumulativa del conflicto colombiano, aunque no exista una relación de causalidad directa o mecánica entre neoliberalismo y conflicto armado interno. A diferencia de países como los centroamericanos que terminaron sus conflictos en medio de la fase neoliberal, el "neoliberalismo aumentó bruscamente el nivel de conflictividad en casi todos los países latinoamericanos", incluido Colombia. ${ }^{99}$

Mediante la Ley 104 de 1993, el Congreso de la República consagró instrumentos para la búsqueda de la convivencia y la eficacia de la justicia; estableció las causales de extinción de la acción penal y de la pena en caso de delitos políticos y conexos; incorporó los acuerdos de paz firmados en 1994 entre el Gobierno Nacional y los grupos insurgentes CRS (9 de abril), Milicias Urbanas de Medellín (26 de mayo) y el Frente Francisco Garnica de la Coordinadora Guerrillera (30 de junio). ${ }^{100}$

En 1994 ocurre un fenómeno particular en la relación entre Estado y paramilitarismo, con la expedición del Decreto 356 el Gobierno Nacional se autorizó la creación de las Asociaciones Comunitarias de Seguridad Rural - CONVIVIR-, con el propósito de apoyar al Ejército aportando información sobre las actividades de la insurgencia, y creando aparatos comunitarios de seguridad privada. Esta situación, facilitó a los grupos paramilitares aumentar su poder y control territorial en zonas como Córdoba, Urabá, Magdalena Medio, Sucre, Sur de Bolívar, Putumayo, Cauca, Meta y Caquetá12. ${ }^{101}$

98 Gaviria, Sentencias Herejías constitucionales, 308.

99 MoncaYo, "Hacia la verdad del conflicto: Insurgencia guerrillera y orden social vigente", 153.

100 Cuenvo Criales, Macrocriminalidad y política de priorización en el marco de la Justicia Transicional, 302.

101 Corte Suprema de Justicia. Sala De Casación Penal. Segunda Instancia Rad. 35367 Justicia y Paz 
En la Ley 241 de 1995, El Congreso de la República prorrogó, modificó y adicionó la Ley 104 de 1993. Abrió la posibilidad de otorgar beneficios jurídicos a los grupos de autodefensa previo abandono voluntario de la organización y la entrega a las autoridades.

La Ley 418 de 1997, en su artículo 131 deroga la Ley 241 de 1995, y prorroga la vigencia, adiciona y modifica la Ley 104 de 1993; e incorpora el Acuerdo de Paz firmado entre el Gobierno Nacional y el MIR-COAR (29 de julio de 1998), al amparo de los Decretos 1247 de 1997 y 2087 de 1998. ${ }^{102}$

Esta ley consideró que los representantes autorizados por el Gobierno Nacional podrían realizar los actos tendientes a entablar conversaciones y diálogos con las organizaciones armadas al margen de la ley a las cuales el Gobierno Nacional les reconozca carácter político. Del mismo modo, podrían adelantar diálogos, negociaciones y firmar acuerdos con sus voceros o representantes, a los cuales el Gobierno Nacional les reconociera carácter político, dirigidos a obtener soluciones al conflicto armado, la efectiva aplicación del Derecho Internacional Humanitario, el respeto a los Derechos Humanos, el cese o disminución de la intensidad de las hostilidades, la reincorporación a la vida civil de los miembros de estas organizaciones y la creación de condiciones que propendan por un orden político, social y económico justo. Para facilitar estos diálogos se suspenderían las órdenes de captura.

Esta normativa se haría extensiva a los grupos de autodefensas, ya que los representantes autorizados por el Gobierno podrían realizar actos tendientes a entablar contactos con las llamadas autodefensas y celebrar acuerdos con ellas, con el fin de lograr su sometimiento a la ley y su reincorporación a la vida civil.103

La Sentencia C-456 de 1997 de la Corte Constitucional, declaró la inconstitucionalidad de los delitos conexos al delito político, prácticamente desconociendo el delito político y disminuyéndolo a una categoría igual a la de los delitos comunes. ${ }^{104}$

Jorge Iván Laverde Zapata. (M.P. Luis Guillermo Salazar Otero, 2012).

102 Cuervo Criales, Macrocriminalidad y política de priorización en el marco de la Justicia Transicional, 302.

103 Ibíd.

104 Si la esencia de la rebelión y la sedición es alzarse en armas, en ambos casos los sujetos activos de estos delitos tienen la pretensión de atacar a la Fuerza Pública estatal con el fin de derrotarla, pues no otra es la finalidad de una insurrección armada. Por ende, los rebeldes o sediciosos causarán, como consecuencia de los combates, daños en los bienes de otros, así como muertes y lesiones personales a los miembros de la Fuerza Pública, pues tales son las inevitables y dolorosas consecuencias de un levantamiento en armas. En tales circunstancias, la inexequibilidad de la norma demandada, según la cual esos delitos no eran punibles si se cometían en combate, equivale a una derogación de las 
En los años inmediatamente anteriores y posteriores al nuevo siglo (gobierno de Andrés Pastrana 1998-2002), se alimentaron las tendencias hacia la negociación con el principal grupo guerrillero, las FARC, y con menor decisión respecto del ELN, que estuvo cerca de un proceso similar bajo la administración presidencial anterior (gobierno de Samper Pizano 1994-1998). Por múltiples razones, entre las cuales se encuentra la ausencia de una definida política de negociación y de concepciones alternativas sobre el Estado y la sociedad, el proceso con las FARC desembocó en ruptura (2002). ${ }^{105}$

La dinámica de ese proceso nunca tuvo claridad política y en medio de él se fue acrecentando la intervención paramilitar, a la par con un mayor involucramiento de los Estados Unidos de América en razón al Plan Colombia. Todas las voces clamaron por la paz, pero la realidad devastadora del desastre se impuso: masacres, desapariciones forzadas, desplazamientos, secuestros, asesinatos y atentados, exilios, destrucción de bienes públicos, afectación del medio ambiente. ${ }^{106}$

En el año 2000, mediante la Ley 599 de 2000, se expide el Código Penal actualmente en vigencia. En el Título XVIII consagra los delitos contra el régimen constitucional y legal,

Artículo 467. Los que mediante el empleo de las armas pretendan derrocar al Gobierno Nacional, o suprimir o modificar el régimen constitucional 0 legal vigente, incurrirán en prisión de noventa y seis (96) a ciento sesenta y dos (162) meses y multa de ciento treinta y tres punto treinta y tres (133.33) a trescientos (300) salarios mínimos legales mensuales vigentes.

Sin embargo, este Código no incluyó ningún artículo que clarificara el contenido de los delitos conexos al delito político. Esto ayudó a que la jurisprudencia de la Corte Constitucional, como de la Corte Suprema de Justicia continuara enfocándose en excluir conductas en vez de fijar positivamente los tipos penales subsumibles al delito polític ${ }^{107}$. De igual manera, incrementa ostensiblemente el quantum punitivo,

disposiciones constitucionales que conceden un tratamiento privilegiado al delito político, diverso a la eventual amnistía o indulto, pues ¿qué sentido tiene que la Constitución señale que no genera inhabilidad ser condenado por rebelión, si la inhabilidad surge de los otros hechos punibles que inevitablemente se cometen durante los combates? ¿0 es que la Corte está imaginando un alzamiento armado sin combates? Esto sería a lo sumo un desfile militar de protesta, pero no una rebelión. Salvamento de Voto a la Sentencia C-456 de 1997 por parte del Magistrado Carlos Gaviria Díaz.

105 Moncayo, "Hacia la verdad del conflicto: Insurgencia guerrillera y orden social vigente", 154.

106 Ibíd.

107 Juan Carlos Forero, y María Angélica Prada. "El resurgimiento del delito político en el proceso de paz con las FARC" En Justicia Transicional en Colombia: Un nuevo camino hacia la paz. (Bogotá: Tirant Lo Blanch, 2017), 95. 
dejando al delito político prácticamente sin esencia, como una mera apariencia y minimizando su carácter noble y altruista, en la medida que, las penas no se diferencian con las impuestas para los delitos comunes.

Con la consolidación del Plan Colombia se produce una reorganización y rearme de las fuerzas militares, las cuales se preparan para confrontar la insurgencia con la reorientación antiterrorista posterior al 11 de septiembre. Así, las insurgencias se convierten en terroristas a los que se tiene que combatir con toda la fuerza militar del Estado, el nuevo enemigo de Estado, el enemigo interno. Esta visión antiterrorista es la que se enmarca en la Política de Seguridad Democrática de Álvaro Uribe.

La Política de Seguridad Democrática tuvo una clara injerencia de los EE.UU, así, se disponen de siete bases militares para el entrenamiento y el diseño de estrategias de las Fuerzas Armadas; se fortalece la acción entre el Ejército y grupos paramilitares, se da un proceso de organización de redes de inteligencias con la participación del DAS, y se presentan los llamados "Falsos Positivos", los cuales consistieron en ejecuciones extrajudiciales que realizaban militares contra jóvenes, principalmente de Soacha, con el fin de obtener beneficios personales en el marco de la lucha contra el terrorismo, en la cual los indicadores más importantes eran: cantidad de guerrilleros dados de baja "neutralizados" o capturados.

En concordancia con la desnaturalización que se presentaba del delito político y la lógica de criminalización a movimientos sociales, defensores de derechos humanos, entre otros, el Gobierno Nacional pretendió incluir la pertenencia o conformación de grupos de autodefensa en el marco de la sedición, es decir, dentro de los delitos políticos. No obstante, la Corte Suprema de Justicia dejó claro que los hechos delictivos cometidos por los paramilitares no fueron ejecutados con el propósito de atentar contra el régimen constitucional, sino que, por el contrario, se llevaron a cabo con el apoyo de importantes sectores institucionales y procurando obtener beneficios personales, estos solo pueden ser entendidos como delitos comunes. ${ }^{108}$

\section{Toma de Posición}

Vemos como durante este periodo (1982-1997) fue viable jurídicamente la consolidación de los procesos de indultos y amnistías, toda vez que el Código Penal de 1980 en el artículo 127 incorporó la norma de esta manera, por eso este instrumento permitió hasta 1997 la consolidación de estos procesos, la posibilidad jurídica de que se pudiera extinguir la pena no solo por los delitos políticos, sino por todos los delitos políticos conexos a estos. Esto es fundamental en tanto que la amnistía es una forma 
de extinción de la pena, al quitar la posibilidad de que los delitos conexos tengan este tratamiento (delito principal) se impide la posibilidad de lograr acuerdos de amnistía 0 desmovilización porque no se cuenta con las herramientas jurídicas para ello.

Con la expedición de la Constitución de 1991 hubo un gran avance desde el punto de vista jurídico constitucional, en tanto que quedó establecido en el artículo 35 que no era posible la extradición por delitos políticos

Sin embargo, con la declaratoria de inexequibilidad del artículo 127 en la Sentencia C-456 de 1997, la Corte Constitucional, en contraposición a lo establecido en el DIH, desnaturaliza el delito político, al criminalizar los delitos conexos a este, situación que se vería reflejada en los futuros procesos de negociación, tal como sucedió en el ámbito de la Ley de Justicia y Paz.

Con la Ley 975 de 2004, Por la cual se dictan disposiciones para la reincorporación de miembros de grupos armados organizados al margen de la ley, que contribuyan de manera efectiva a la consecución de la paz nacional y se dictan otras disposiciones para acuerdos humanitarios, se desarrolló el primer contexto de justicia transicional bajo los principios de verdad, justicia, reparación y no repetición para los postulados que se acogieran a esta Ley, esto es, grupos de autodefensas que se desmovilizaron de manera colectiva e integrantes de los grupos insurgentes, de manera individual, desconociéndose la naturaleza del delito político.

La razón de ser esta ley era que, a cambio de que los postulados confesaran ${ }^{109}$ los hechos que tuvieron ocurrencia durante y con ocasión del conflicto armado, y en los cuales participaron, tenían derecho a la pena alternativa que consiste en privación efectiva de la libertad entre cinco y ocho años físicos, sin beneficios.

Pero como en los demás procesos que hemos visto, las reglas del juego volvieron a cambiar: Lo primero fue la extradición a Estados Unidos de los comandantes de las Autodefensas Unidas de Colombia - AUC- que se habían desmovilizado como consecuencia de la Ley; luego, la pena alternativa se convirtió en pena indefinida, pues en la ley no se aclaró, desde que momento se empezaban a contabilizar los 8 años; finalmente, siete años más tarde, se expidió la Ley 1592 de 2012 que dijo desde

109 La confesión y la verdad, tienen en su esencia el mismo carácter, en la confesión, quien habla se obliga a ser lo que dice ser, se obliga a ser quien ha hecho tal o cual cosa. En sentido estricto, sólo hay confesión dentro de una relación de poder a la que aquella brinda oportunidad de ejercerse sobre quien confiesa. Las cosas son evidentes cuando dichas relaciones de poder se definen institucionalmente. Haciendo la analogía con el caso que describe Foucault, el loco y Leuret, en este caso es el delincuente político que por medio de la confesión se obliga a ceder y se expone al poder que en este caso, el Estado pretende ejercer sobre él. Al aceptar hay un sometimiento. MichaEL Foucault. Obrar mal, decir la verdad la función de la confesión en la justicia. (Buenos Aires: Siglo XXI, 2014), 24-27. 
cuando se empezaba a contar el tiempo para la pena alternativa; sin embargo, la Corte Constitucional en la sentencia C-015 de 2014 aclaró que para los ex miembros de estos grupos el tiempo se empezaba a contabilizar desde la fecha de la postulación; lo que significó que a pesar de que muchos se habían desmovilizado años atrás como consecuencia de esta ley, pero que fueron postulados por el Gobierno Nacional años después, no se les tuvo en cuenta los años desde la desmovilización.

Adicionalmente a esto, muchos postulados que habían confesado hechos ocurridos durante y con ocasión del conflicto armado, por diferentes razones fueron excluidos de Justicia y Paz y se les compulsó copias a la Justicia Ordinaria sobre los nuevos hechos confesados, pagando condenas por delitos sobre los cuales ya habían sido condenados.

El Estado incumplió de muchas maneras la consecución de esa paz estable y duradera en Justicia y Paz; también lo hicieron algunos de los postulados, cuando se dieron cuenta que no se había cumplido con el objeto de la Ley.

Cambian las formas, cambian las personas, cambian las instituciones, pero no cambia la necesidad de confesar los crímenes, ya que es necesario, legitimar el poder punitivo y la mejor forma de hacerlo es cuando se admite la responsabilidad, se reconocen los crímenes, se pide perdón que debe venir con arrepentimiento y se repara a las víctimas.

Con las reformas constitucionales contenidas en los Actos Legislativos 01 y 02 de 2017, las leyes 1820 de 2016, 1922 de 2018 y 1957 de 2019, se implementa el Acuerdo suscrito el 24 de noviembre de 2016 entre el Gobierno Nacional y las FARC con el fin de lograr, finalmente, una paz estable y duradera.

El aspecto de mayor relevancia de este nuevo proceso de paz, es que se acuerda que son las víctimas del conflicto armado el eje central del Acuerdo; por ello, el SIVJRNR está dirigido a los ex integrantes de las FARC, a los agentes del Estado, que incluye a la fuerza pública, a los terceros que colaboraron o financiaron estos grupos y a las personas que están siendo procesadas o condenadas por la protesta social.

Para acceder a los beneficios que otorga el Acuerdo, es necesario cumplir lo que se ha denominado un régimen de condicionalidad, esto es, cumplir con estándares de verdad, reparación y no repetición suficientes para acceder a las sanciones penales que otorga la Jurisdicción Especial para la Paz.

Con la expedición de la Ley 1820 de 2016, de amnistía, indultos y tratamientos penales especiales, se reconoce nuevamente la naturaleza del delito político, los cuales son considerados como aquellos en los cuales el sujeto pasivo de la conducta ilícita es el Estado y su régimen constitucional vigente, cuando sean ejecutados 
sin ánimo de lucro personal. Frente a la realización de conductas delictivas, se establece un régimen de sanciones, que de acuerdo al grado de reconocimiento de responsabilidad y al aporte de la verdad se imponen a los juzgados. ${ }^{110}$

No solo se ha incumplido el Acuerdo en relación con la Reforma Rural Integral, las Garantías para la Participación política, la Sustitución de Cultivos; sino que los órganos que integran el Sistema Integral tampoco brindan la protección a los desmovilizados para evitar la continuación del patrón de incumplimiento del Estado, como hemos visto en todos estos procesos de pacificación; esto, es, la etapa de aniquilamiento.

De esta forma, el incumplimiento del Estado en el Acuerdo suscrito con las FARC mantiene el mismo patrón: el Estado negocia solo con un grupo, exige la dejación 0 entrega de las armas, concede amnistía e indultos, reduce penas a cambio de legitimidad por parte de los vencidos y emprende nuevamente, la etapa de aniquilamiento de quienes se han amnistiado. Cada vez lo hace con formas más sofisticadas.

El integrante de la Comisión de la Verdad, Saúl Franco, sostuvo que se sigue repitiendo en el país amenazas y ataques contra líderes sociales y ahora excombatientes. Indicó que en las últimas tres décadas se han reinsertado 48.400 personas y de ellas 3.514 han sido asesinadas. "Las cifras sí importan, no lo dicen todo, pero dicen mucho, que un país a quienes tienen el valor de dejar las armas, les quiten la vida en esta magnitud es algo muy preocupante", dijo el Comisionado tras señalar que se evidencia que pasa algo muy grave en la conciencia del país y el ejercicio de la democracia.

Añadió que estos crímenes no son producto de simples pistoleros y que no son hechos aislados. "No podemos caer en la ligereza de algunos altos funcionarios del Estado de desvalorizar o quitarles significado a estas vidas que estamos perdiendo y a esta cantidad de amenazas que se siguen repitiendo", indicó.

Y agregó que son 185 los muertos de las Farc y que hay apatía del país frente a esas muertes. ${ }^{111}$

La política es la continuación de la guerra por otros medios ${ }^{112}$, un claro ejemplo del resultado del Acuerdo del 24 de noviembre de 2016, donde la clase política que

110 Ley 1820 de 2016. Por medio de la cual se dictan disposiciones sobre amnistía, indulto y tratamientos penales especiales y otras disposiciones.

111 "Comisión de la Verdad alerta por crímenes contra excombatienes FARC" El Tiempo. https:// www.eltiempo.com/justicia/investigacion/es-critica-la-situacion-de-los-excombatientes-de-lasfarc-470720. A la fecha, resultan ser más de 200 los ex combatientes asesinados por las FARC.

112 Clausewitz, De la guerra. 
ha fomentado la guerra y el odio en este país, se opuso a cualquier tipo de acuerdo e insidio en la negativa del pueblo para firmar la paz. De ahí, que se deslegitimó cualquier posibilidad de terminación de la guerra y como hemos podido observar a lo largo de este escrito, la repetición cíclica del conflicto se mantiene hoy más latente que nunca, pero bajo otras formas.

\section{Conclusiones}

En síntesis se puede afirmar que

a). Delito político:

En el recorrido histórico y normativo del delito político en el ámbito jurídico penal se pudo constatar que, el tratamiento jurídico-penal guarda una relación directa con el contexto político en cada momento histórico. Es así como observamos que el primer tratamiento dado hacia el delito político fue con la pena capital; luego, en los procesos de transformaciones más liberales, se logró sustituir por la expulsión del territorio; con la Constitución de 1886, de corte conservador, se restablece la pena de muerte, la cual es abolida en 1910. Pero fue solamente con la entrada en vigencia del Código Penal de 1936, es decir, bajo el gobierno liberal de Alfonso López Pumarejo, que se reconoce el carácter altruista del delito político, que se preserva hasta 1997.

Como consecuencia del Acuerdo de la Habana, mediante la Ley de amnistía, se restablece nuevamente la naturaleza del delito político, pero con carácter exclusivo para el grupo insurgente desmovilizado.

De igual manera, la criminalización del otro se ha utilizado como mecanismo de control social, de represión, bajo argumentos de luchas contra enemigos internos, el derecho penal ha actuado en esta lógica.

b). Amnistías:

La figura de la amnistía se ha configurado como mecanismo de rendición del enemigo cuando el Estado no tiene la capacidad para aniquilarlo. Es un mecanismo de transformar la guerra sometiendo al otro, no mediante las armas, sino mediante el otorgamiento del perdón que trae consigo el sometimiento y la aceptación de la negación de la razón de la lucha, a cambio de la disminución o extinción de la sanción penal.

Lo que trae implícito la amnistía, el armisticio, las capitulaciones, es acabar la voluntad de la lucha del otro. Esto no ha sido ajeno al Acuerdo entre las FARC y el Gobierno Nacional, pues se ve reflejado en este proceso, la exigencia de perdón, 
arrepentimiento, confesión, contrición y negación de la razón de la sublevación, a cambio de una sanción que puede ser simbólica, pero que en el fondo constituye la rendición y el sometimiento.

Como se puede constatar, la violencia en Colombia ha estado presente a lo largo de su historia y presenta una dinámica de insurrección permanente con los posteriores acuerdos, amnistías e indultos y el consecuencial incumplimiento en cada uno de estos procesos. Se han realizado de manera permanente políticas de pacificación, generando terror en la población y recrudeciendo la violencia en cada una de las épocas.

c). Incumplimiento:

En el contexto de la guerra en Colombia, todos los procesos tendientes a buscar un acercamiento para la paz son incumplidos por el Estado, una vez que los desmovilizados de los grupos deponen las armas; pues, ya el Estado no tiene que combatirlos y sus obligaciones dejan de ser vinculantes; y como consecuencia de ello, el Estado cumple su propósito:

Abatir al adversario e incapacitarlo para que no pueda proseguir con su resistencia. (...) imponer nuestra voluntad al enemigo es el objetivo. Para estar seguros de alcanzar este objetivo tenemos que desarmar al enemigo, y este desarme constituye, por definición, el propósito específico de la acción militar: reemplaza al objetivo y en cierto sentido prescinde de él como si no formara parte de la propia guerra. ${ }^{113}$

Al finalizar el año 2019 Colombia entró en un periodo de movilización social que conlleva a recordar que los problemas, las diferencias, los odios y las divisiones sociales, siguen estando presentes en la sociedad; así mismo, que los poderes que han gobernado este país han sembrado siempre la lucha constante entre las clases populares por unos mínimos, mientras que el país sigue siendo repartido entre unos pocos; que a partir de la narrativa de los "monstruos" o enemigos internos (liberalismo, masonería, comunismo, terroristas, castrochavismo, Venezuela, Cuba, entre otros) han facilitado el control social de los sujetos.

Hasta que no se dé una solución a los problemas estructurales en materia económica, social, política, cultural, no va a producirse una terminación del conflicto, este, se seguirá transformando como ha sucedido a lo largo de estos 200 años de vida republicana. 


\section{Bibliografía}

Agullera, Mario Y Renán Vega Cantor. Ideal democrático y revuelta popular. CEREC, 1998.

BushnelL, David. Colombia: una nación a pesar de sí misma. Bogotá: Editorial Planeta, 2014.

Caicedo, Daniel. Viento Seco. 1954.

Clausewitz, Karl Von. De la guerra. 2002. https://lahaine.org/amauta/b2-img/ Clausewitz\%20Karl\%20von\%20-\%20De\%20la\%20guerra.pdf

Corte Suprema de Justicia. Sala de Casación Penal. Segunda Instancia Rad. 35367 Justicia y Paz Jorge Iván Laverde Zapata. (M.P. Luis Guillermo Salazar Otero, 2012).

Corte Suprema de Justicia. Sala de Casación Penal. Segunda Instancia 34547. Sentencia Cobos y Banquez. (27 de abril de 2011).

Cuervo Criales, Beatriz. Macrocriminalidad y política de priorización en el marco de la Justicia Transicional. Barcelona: 2016.

Fals Borda, Orlando. Una sociología sentipensante para América Latina. México D.F: Siglo XXI, 2015.

FerRajolı, Luigi. Derecho y razón. Teoría del garantismo penal. Madrid: Editorial Trotta, 1995.

Forero, Juan Carlos Y María Angélica Prada. "El resurgimiento del delito político en el proceso de paz con las FARC" en Justicia Transicional en Colombia: Un nuevo camino hacia la paz. Bogotá: Tirant Lo Blanch, 2017.

Foucault, Michael. La verdad y las formas jurídicas. Barcelona: Grijalbo, 1995.

Foucault, Michael. Obrar mal, decir la verdad la función de la confesión en la justicia. Buenos Aires: Siglo XXI, 2014.

Gaviria Díaz, Carlos. Sentencias Herejías Constitucionales. Bogotá: Fondo de Cultura Económico, 2002.

González, Fernán. Poder y violencia en Colombia. Bogotá: Odecofi CINEP, 2014.

Guzmán, German, Orlando Fals Borda y Eduardo Umaña Luna. La violencia en Colombia. Tomo 1. Bogotá: Panamericana. http://diposit.ub.edu/dspace/ bitstream/2445/108272/1/BdPCC _ TESIS.pdf

Ley 1820 de 2016. Por medio de la cual se dictan disposiciones sobre amnistía, indulto y tratamientos penales especiales y otras disposiciones. 
Marouez Estrada, José. "La nación en el Cadalso. Pena de muerte y politización del patíbulo en Colombia 1800-1910", Revista Historia y Memoria, n. 5, (2012).

Medina Gallego, Carlos. "Una propuesta para la periodización de la historia del conflicto colombiano en el siglo XX", en Para reescribir el siglo XX. Memoria, insurgencia, paramilitarismo y narcotráfico, coordinado por Guerrero, Javier, y Acuña, Olga. Bogotá: La Carreta Editores.

Medina Gallego, Carlos. FARC-EP, Notas para una historia política 1958-2006. Centro de Documentación de los Movimientos Armados.

Molano Bravo, Alfredo. "Fragmentos de la historia del conflicto armado (1920-2010)", en Contribución al entendimiento del conflicto armado en Colombia, 2015.

Moncayo, Víctor Manuel, "Hacia la verdad del conflicto: Insurgencia guerrillera y orden social vigente", en Contribución al entendimiento del conflicto armado en Colombia, 2015.

Palacios Preciado, Jorge, "La esclavitud y la sociedad esclavista", en Manual de Historia de Colombia Tomo 1, coordinado por Jaime Jaramillo Uribe. Procultura, Instituto Colombiano de Cultura, 1971.

Palacios, Marco y Frank Safford, Historia de Colombia. País fragmentado, sociedad dividida. Bogotá: Universidad de los Andes, 2013.

Parada García, Gllberto. “Orden y revolución en la ley penal colombiana (1819-1837). Un debate historiográfico", en Anuario Colombiano de Historia Social y de la Cultura, $36, n^{\circ} 2$.

Parada García, Gilberto. "Una historia del delito político. Sedición, traición y rebelión en la justicia penal neogranadina (1832-1842)", en Anuario Colombiano de Historia Social y de la Cultura, 39, $n^{\circ} 2$,

Peraza Correa, Hernando. Amnistías, indultos y perdones, entre la insurrección comunera y las conversaciones de la Habana. Bogotá: Universidad Sergio Arboleda, 2014.

Renán Vega Cantor y Eduardo Rodríguez. Economía y violencia. Bogotá: Fondo de Publicaciones de la Universidad Distrital Francisco José de Caldas, 1990.

Reyes Alvarado, Yesid. "Colombia, Entre la guerra y la paz", Revista IUSTA, 2005.

Salazar Cáceres, Carlos. "Breve historia del derecho penal colombiano", Revista Principia luris, 13, nº 26.

Tenorio Obando, Felipe. "Amnistías en Colombia: Herramienta de engaño, herramienta política y mecanismo de reconciliación" en Justicia Transicional en Colombia: Un camino hacia la paz, coordinado por Juan Carlos Forero. Tirant Lo Blanch, 2017. 
Tribunal Superior De Distrito Judicial. Sala de Justicia y Paz, Radicación 11001600253200680008 N.I.1821. (M.P. Alexandra Valencia Molina, 31 de octubre 2014).

UniBe, María Teresa. "Las guerras civiles y la negociación política: Colombia, primera mitad del siglo XIX", Revista de Estudios Sociales, 2003.

Valencia Villa, Hernando. Cartas de Batalla. Bogotá: Panamericana, 2010.

Vega Cantor, Renán. Gente muy rebelde. Tomo 2. Indígenas, campesinos y protestas agrarias. Bogotá: Editorial Pensamiento Crítico, 2002.

Vega Cantor, Renán. Gente muy rebelde. Tomo 4. Socialismo, cultura y protesta popular. Bogotá: Editorial Pensamiento Crítico. 